\title{
LA EMPRESA COMO OBJETO DE NEGOCIOS JURÍDICOS: ÉNFASIS EN LA COMPRAVENTA DE EMPRESAS ${ }^{1}$
}

\author{
Ruth Elizabeth Rojas Mercado \\ Labora en el Banco Central de Nicaragua
}

\section{Resumen}

El artículo aborda temas referidos al concepto de empresa, dejando sentado que no existe un concepto unívoco de ésta y solamente el Código del Trabajo en su artículo 12 define un concepto pero no responde a las actuales necesidades jurídicas mercantiles del país. Se desarrolla el contenido relacionado a la empresa como objeto de negocios jurídicos y sus formas de transmisión como son la inter vivos en sus diferentes manifestaciones jurídicas a saber el arrendamiento; el usufructo; la hipoteca y la compraventa como negocio jurídico por excelencia pero que en nuestra legislación no se encuentra regulada por lo que se recurre a la aplicación del principio de la autonomía de la voluntad y la libertad de contratación y resto de ordenamiento jurídico aplicable. La otra forma de transmisión de la empresa es por causa de muerte, que es cuando el empresario transmitente es una personal natural o empresario individual.

De igual forma, se expone el tema referido a los sujetos de la actividad mercantil, tal y como lo establece el Código de Comercio de nuestro país al utilizar el término de comerciante, siendo un vocablo inexacto dado que producto del desarrollo económico social el comerciante no solo se dedica al comercio sino que también puede desempeñarse en la industria o producción por lo que el término jurídico adecuado es el de empresario.

Palabras clave: empresa/ transmisión/ patrimonio/ contrato

\section{Introducción}

Vale la pena señalar que es imposible que algo sea al mismo tiempo sujeto y objeto de negocios jurídicos, y la empresa no es la excepción.

No existe un concepto jurídico unívoco de empresa, generalmente las categorías jurídicas lo hacen ancladas en su concepto económico. Ésta es considerada como una especifica modalidad de riqueza económica

1 El presente artículo es el resultado del trabajo de investigación realizado para obtener el título de Máster en Derecho de Empresas con Especialización en Asesoría Jurídica; el cual además de ser evaluado por un Tribunal integrado por tres académicos; posteriormente, fue arbitrado por una Comisión a efectos de seleccionar a los participantes del I Encuentro de Investigación de Postgrado de la Universidad Centroamericana, 2009. 


\section{Revista de ODerecho}

compuesta de distintos elementos de naturaleza disimil y debidamente organizados por su titular, el empresario, en pos de la prestación de bienes o servicios para el mercado.

Siendo una realidad jurídica la empresa puede ser transmitida cambiando la titularidad de la misma. Lo que lleva a concluir que los distintos negocios jurídicos de transmisión de la empresa conllevan a que la misma cambie de titularidad, pudiendo ser adquirida tanto por persona física -empresario individual- como por persona jurídica.

El contrato por el cual la empresa debe ser transmitida, tanto definitiva como temporalmente, es único, aunque la entrega efectiva se descomponga en una pluralidad de transmisiones particulares de sus distintos elementos simples, sujetas cada una de ellas a la ley de circulación propia del bien o elemento que deba transmitirse. En nuestra legislación no existe regulación alguna sobre la transmisión directa de la empresa y sus distintas formas, sin embargo, en virtud del principio de autonomía de la voluntad, puede efectuarse la misma apoyándose en las distintas normas jurídicas que deban aplicarse según la naturaleza de los elementos en que se compone la empresa.

Por antonomasia, el negocio arquetípico de transmisión inter vivos de la empresa es la compraventa aunque la misma puede transmitirse por otras modalidades tales como el arrendamiento, permuta, dación en pago, usufructo, y aun por causa de muerte, a través de la herencia o legado.

\section{La empresa para el Derecho Mercantil moderno}

Dentro del Derecho privado, se define como Derecho Patrimonial aquella parte reguladora de las personas como sujeto de la economía y sus relaciones en el ejercicio de las actividades económicas (producción, distribución, atribución, disfrute y consumo de bienes y servicios). La esfera patrimonial constituye una proyección de la persona en el sistema económico, un ámbito de poder inherente a toda persona y necesario para la realización de sus fines ${ }^{2}$. El Derecho patrimonial está dividido en dos ramas: el Derecho civil patrimonial y el Derecho Mercantil, la

2 Constituyendo el patrimonio, desde un punto de vista jurídico, el conjunto de relaciones activas y pasivas pertenecientes a una persona que poseen un valor económico. DIEZ-PICAZO, Sistema de Derecho Civil, 1978, 433. 


\section{Revista de ODerecho}

relación entre ambos corresponde con la que existe entre Derecho común y Derecho.

El sector de la realidad patrimonial regulado por las normas del Derecho Mercantil ha de estructurarse en torno a la empresa como organización económica. No quiere decir esto que el Derecho Mercantil sea el Derecho de la empresa. Es ésta una compleja categoría del campo de la economía, que no constituye materia exclusiva de ninguna rama jurídica. La empresa es una organización que reconduce a unidad elementos muy diversos y envuelve en su seno elementos personales, materiales, inmateriales y relaciones jurídicas y de hecho que se rigen por distintas ramas del ordenamiento jurídico. Normas del Derecho patrimonial privado común (como las que rigen los derechos reales sobre elementos de la empresa), o de Derecho público económico (como las relativas a licencias o autorizaciones administrativas), o de Derecho del Trabajo (reguladoras de las relaciones laborales), inciden en el ámbito de la empresa, y no son mercantiles. La empresa no constituye, pues, contenido exclusivo del Derecho Mercantil, ni éste penetra en el ámbito interno de su organización ${ }^{3}$.

El valor de la empresa para el Derecho Mercantil no es propio de su contenido, sino el de concepto previo de referencia, que sirve como dato calificador de su titular (el empresario) y de su actividad externa (el tráfico empresarial). Éstos - personas y actividad- sí integran el contenido propio del Derecho Mercantil. La empresa constituye el concepto previo y ordenador del contenido del Derecho Mercantil, calificador de su titular (el empresario) y de su actividad externa (el tráfico empresarial) ${ }^{4}$.

Por eso, el Derecho Mercantil en la actualidad se ve configurado como el ordenamiento profesional de las empresas, es decir de las empresas y de su tráfico, que como se afirmó anteriormente, no por esto se debe identificar al Derecho Mercantil con el Derecho de la empresa, ya que esto no es exacto absolutamente, debido a que la empresa está integrada por dos factores productivos esenciales: capital y trabajo, y el Derecho Mercantil no regula uno de los elementos integrantes de la empresa (el trabajo cuyo régimen corresponde al Derecho Laboral), por lo que no puede afirmarse sin más que el Derecho Mercantil es el derecho de

3 JIMENEZ SÁNCHEZ, GUILLERMO, Lecciones de Derecho Mercantil, 2004, 39 a 40.

4 idem, Pag. 42. 


\section{Revisla de Derecho}

la empresa, para que esto fuera exacto sería necesario que todas las disposiciones que rigen a la empresa fueran mercantiles cosa que no es así pues ésta está sujeta a varias disciplinas jurídicas, y especialmente, al Derecho Laboral y Fiscal 5 .

La empresa es el elemento fundamental de la economía moderna, por ello es un elemento de la organización económica sometida a regulación o tratamiento jurídico. Al Derecho Mercantil de la empresa tan sólo le interesa porque su explotación confiere a su titular la condición de empresario mercantil (el comerciante de nuestro Código de Comercio nicaragüense); porque su actividad económica de relación con el mercado (que realiza el empresario por medio de una empresa) está sometida a esta disciplina; porque en la empresa existen elementos regulados por el Derecho Mercantil (arrendamiento de locales, marcas, nombre comercial, patentes, etc.); y, finalmente, porque la empresa es objeto frecuente de tráfico económico (se vende, se arrienda, se hipoteca, etc.) ${ }^{6}$.

\section{Sujeto del Derecho Mercantil moderno ¿Comerciante o empresario?}

En sus orígenes el Derecho Mercantil contemplaba exclusivamente a los comerciantes como sujetos de la actividad mercantil7.

En la actualidad el término comerciante ha venido a ser sustituido por el de empresario. El empresario es una noción mucho más amplia, que comprende a todas las personas que disponen de una organización de elementos personales, materiales e inmateriales para producir bienes o servicios para el mercado. En la realidad actual, ya no existe esa correspondencia entre comercio y actividad mercantil. El comercio es sólo un sector de esa actividad, y el comerciante una clase de empresario. Empresario es la persona física o jurídica que se sirve de una empresa para realizar en nombre propio una determinada actividad económica. Es, pues, el sujeto agente de la actividad económica, es el servidor de la empresa $^{8}$.

Empero, nuestro Código de Comercio nicaragüense, denomina a este sujeto "comerciante" y no "empresario", lo cual es una denominación

\footnotetext{
5 BROSETA PONT, Manual de Derecho Mercantil, 2002, 80.

6 idem, Pag. 81.

7 BERCOVITZ RODRÍGUEZ-CANO, Apuntes de Derecho Mercantil, 2002, 119.

8 BROSETA, ob. cit, Pag. 73.
} 


\section{Revista de ODerecho}

inexacta, porque el empresario no solo extiende su actividad hacia el comercio, sino también a la industria o producción, por lo que debe sustituirse el término comerciante por el de empresario.

\section{Empresario mercantil (el elemento personal de la empresa)}

Se distinguen dos elementos esenciales en la empresa mercantil, que son el elemento subjetivo y el elemento objetivo. Componen el elemento subjetivo: el empresario y el personal; el objetivo está integrado por elementos patrimoniales y las relaciones jurídicas que se requieren para la consecución de los fines de la empresa9.

Las organizaciones empresariales requieren de un sujeto al cual le sean jurídicamente atribuidas y que venga investido del poder jurídico que permita su ejercicio. Donde hay una empresa ha de haber un empresario. Pero habida cuenta que la empresa es actividad y además organización de medios no sólo materiales e inmateriales sino, también, personales, cualquiera sea el tipo de organización jurídica (persona individual, persona jurídica) siempre hay un sujeto de la actividad empresarial: un empresario, es decir, siempre ha de haber un centro de imputabilidad ${ }^{10}$.

La particularidad del derecho español permite afirmar la existencia de empresarios mercantiles (comerciante) al lado de otros empresarios de los que no puede predicarse su mercantilidad como lo son los empresarios públicos, los artesanos, los agricultores. Además, se consideran como empresarios civiles a los pequeños empresarios, que realizan una actividad económica en nombre propio sin disponer de una verdadera empresa, los empresarios agrícolas individuales - aunque si ejercitan esta actividad a través de una sociedad anónima o de responsabilidad limitada se convierten en mercantiles ${ }^{11}$. Así permite la diferencia de los empresarios públicos, configurado por entidades estatales que ejercen una actividad empresarial de prestación de productos o servicios para el mercado.

El artículo 6 de nuestro Código de Comercio establece el concepto legal de comerciante o empresario individual, entendiéndose por éstos "los que se ocupan ordinaria y profesionalmente en alguna o algunas de las operaciones que corresponden a esta industria”. A esta definición hay

9 BAUCHE GARCIADIEGO, La Empresa, 1977, 53.

10 GIRÓN TENA, Apuntes de Derecho Mercantil, La Empresa, 1977-1978, 57-58.

11 BROSETA, ob. cit, Pag. 64-65. 


\section{Revista de ODerecho}

que añadir el requisito de gozar de la capacidad civil plena o capacidad legal, o sea ser mayor de edad, y tener la libre disposición de sus bienes (Art. 278 C). Nuestra legislación no establece acápites excluyentes de los artesanos o agricultores como sujetos empresariales a los cuales se les salve de la aplicación del régimen mercantil; claro está que en el caso de los empresarios públicos se rigen por normas de orden público y en lo que les será aplicable las normas mercantiles se utilizarán éstas de manera complementaria.

No obstante, siempre existirá la identificación del sujeto comerciante (empresario) por la utilización de criterios subjetivos como aquél que se ocupa ordinaria y profesionalmente de operaciones que son consideradas estrictamente mercantiles (constituidos éstos ya sea como empresarios individuales o como sociales debiendo cumplir determinadas obligaciones para su constitución) y siendo su actividad empresarial dirigidas a la ejecución de actos de comercio (o empresariales en un mejor sentido).

La atribución a una persona natural o jurídica de la condición de empresario comporta el sometimiento a un estatuto especial que, por el contrario, no es de aplicación a quienes no ostentan esa condición. Este estatuto está integrado por dos deberes legales: 1) la llevanza de una contabilidad ordenada, y 2) el deber de inscripción del propio empresario (lo cual es medio de prueba, estableciéndose como una presunción iuris tantum de mercantilidad sobre el sujeto) y de determinados actos en el Registro $^{12}$.

En la actualidad se ha creado un nuevo concepto, el de operador económico, el cual se entiende como toda persona que realiza operaciones de mercado, tanto desde el lado de la oferta, como desde el lado de la demanda, busque o no busque un lucro con su actuación y tenga o no tenga una organización para participar en el mercado.

Este concepto trata de superar el término empresario por un concepto más amplio y fresco. Por consiguiente, los consumidores serían también operadores económicos. Es importante el hecho de considerar operadores económicos a las personas jurídicas que actúan en el mercado; tanto si actúan con ánimo de lucro, como si actúan exclusivamente desde el lado

12 ROJO, ÁNGEL, «El empresario (I). Concepto, Clases y Responsabilidades», «El Establecimiento mercantil», en Curso de Derecho Mercantil, I, 1999,101. 
de la demanda. En definitiva, por tanto, se parte de la idea de que las normas legales que rigen el mercado deben aplicarse a todos los que participan en el, es evidente que su ámbito subjetivo ha de ser no sólo el de los empresarios, si no el de los operadores económicos en general. Y este ámbito subjetivo tiene especial trascendencia, como acaba de señalarse, para incluir en él a todos los operadores personas jurídicas, esto es, no sólo las sociedades mercantiles, sino también, asociaciones y otras personas jurídicas que actúan en el mercado ${ }^{13}$.

2.1. Clases de empresarios: Empresario individual y Empresario social. Cooperativas, Asociaciones y Fundaciones

La empresa como conjunto organizado de medios de distinta naturaleza tiene autonomía frente al empresario ${ }^{14}$, en el sentido de que puede transmitirse de una persona a otra distinta, esto es, puede cambiar el empresario. El empresario es por tanto absolutamente imprescindible para que la organización de medios en que consiste la empresa pueda participar en el mercado. Quien adquiere los derechos y obligaciones es el empresario, no la empresa que carece de personalidad jurídica propia. El empresario no necesita ser el propietario de la empresa como conjunto organizado de medios. Basta con que la actividad empresarial se desarrolle en nombre del empresario ${ }^{15}$.

Como tal en la realidad jurídica existen dos tipos de personas empresarios- que en la actividad económica empresarial interesan al Derecho como titular de la empresa, esto es el empresario individual (persona natural) y el empresario social (persona jurídica).

En caso de comerciantes individuales (empresario individual), el empresario es aquel en cuyo nombre se explota la empresa y que normalmente invierte el capital para operar la misma, como resultado de lo cual responde con todos sus bienes de las obligaciones de la empresa y tiene control sobre sus actividades ${ }^{16}$.

13 BERCOVITZ, ob. cit. Pág. 128-129.

14 Este sujeto es el empresario, quien tiene capacidad jurídica. Por ello cuando en las normas legales se hace referencia a la empresa como sujeto de derecho u obligaciones, realmente a quien se refiere la norma es al empresario, que es el único que puede asumir derechos y obligaciones.

15 idem, Pag. 176.

16 GUTIÉRREZ FALLA, Derecho Mercantil, 1985, 70. 


\section{Revista de Derecho}

La figura del empresario mercantil individual aparece cuando una persona física realiza en nombre propio (o mediante representante ${ }^{17}$ ) y por medio de una empresa una actividad económica comercial o industrial, sometiéndose a un estatuto de contenido especial, no obstante su patrimonio no está separado del resto de su patrimonio civil, no existiendo, al final, distinción alguna entre sus obligaciones civiles y mercantiles.

En cuanto al empresario mercantil colectivo o social, es aquel cuya esencia está constituida por la participación de distintas personas, física o jurídica, que conforman una persona jurídica distinta de ellos la cual es titular de los derechos y obligaciones ${ }^{18}$. Siendo el empresario mercantil, en el presente caso, ninguna de las personas físicas o jurídicas que se asocian, sino la persona jurídica nueva y distinta que se crea para realizar aquella actividad ${ }^{19}$.

En la actualidad existe una agitada tendencia hacia el predominio de los empresarios colectivos sobre los individuales, lo cual se debe al hecho de que la economía moderna exige la acumulación de grandes masas de capital por la explotación de sus actividades ${ }^{20}$.

Existe la duda de que si la mera existencia de una sociedad es suficiente para crear una empresa. Sostener que las sociedades son siempre empresarios es crear la categoría de empresarios sacramentales, empresarios por adopción de forma. Se considera insostenible afirmar que la sociedad, desde el momento de su constitución (sólo por tener dinero depositado en el banco) puede considerarse, a todos los efectos legales, un empresario, cuando lo cierto es que le faltan no sólo los elementos materiales (maquinaria, equipo, personal, etc.), necesario

17 Ya que el derecho no exige en el empresario un despliegue de actividad directa y personal, le basta con que la actividad empresarial se ejercite en su nombre, aunque de hecho venga desarrollada por personas delegadas.

18 Nuestro Código de Comercio no define de manera general el concepto de sociedad, se limita a definir los tipos sociales -aunque no todos, pues no define la sociedad colectiva como tal-. Por tal razón, recurrimos a lo que establece el Código Civil como definición de sociedad en su artículo 3175. "Se llama sociedad el contrato en virtud del cual, los que pueden disponer libremente de sus bienes o industrias, ponen en común, con otra u otras personas, esos bienes o industrias, o los unos y las otras juntamente con el fin de dividir entre sí el dominio de los bienes y las ganancias y pérdidas que con ellos se obtengan, o sólo las ganancias y pérdidas."

19 El comerciante es la sociedad y no sus accionistas, que son meros inversionistas en el capital de la persona jurídica.

20 BROSETA, ob. cit. Pág. 74. 


\section{Revista de Derecho}

para poder desarrollar la empresa, sino inclusive los elementos dinámicos, como la coordinación y la profesionalidad, imprescindibles para tipificar la misma. Una cosa es la organización de la empresa social y otra la organización de la sociedad; la primera es la organización de la actividad económica ejercida profesionalmente, mientras que la segunda es la organización del sujeto que ejerce dicha actividad. Por tal razón, se afirma que la mera existencia de la sociedad (empresario que organiza la empresa) no acarrea la existencia de la empresa ${ }^{21}$.

\subsection{Otros sujetos jurídicos (empresarios)}

Al lado de los diversos tipos de sociedad mercantil existe en nuestro derecho positivo otras formas sui generis de organización de colaboración de una pluralidad de personas tales como las cooperativas, las fundaciones, y las asociaciones, que por la doctrina jurídica son también consideradas como empresarios. A éstas se les reconoce constitucionalmente rol protagónico como iniciativa privada en el ejercicio de las actividades económicas ${ }^{22}$, aunque su actividad no tenga un fin de lucro.

Las cooperativas están definidas en nuestra legislación como "una asociación autónoma de personas que se unen voluntariamente para hacer frente a sus necesidades y aspiraciones económicas, sociales $y$ culturales comunes por medio de una empresa de propiedad conjunta y democráticamente controlada ${ }^{23}$; ; dirigido su objeto a explotar, pues, una empresa o actividad económica en interés directo de sus cooperados, por tanto nuestra legislación considera a las cooperativas como sujetos jurídicos cuyo medio para conseguir sus fines es la empresa de propiedad conjunta, por lo cual la mayor parte de las normas que integran el estatuto del empresario son aplicables a las cooperativas.

Por lo que se refiere a las fundaciones y asociaciones, que son también modalidades de operadores económicos, si realizan actividades mercantiles le son aplicables las normas que regulan dicho ámbito

21 GUTIÉRREZ, ob. cit. Pág. 71

22 Artículo $99 \mathrm{Cn}$. "El ejercicio de las actividades económicas corresponde primordialmente a los particulares. Se reconoce el rol protagónico de la iniciativa privada, la cual comprende en un sentido amplio, a grandes, medianas y pequeñas empresas, micro empresas, empresas cooperativas, asociativas y otras."

23 Artículo 5 de la Ley No. 499 "Ley General de Cooperativas", Publicada en La Gaceta, Diario Oficial No. 17 del 25 de Enero de 2005. 
jurídico. Dichas personas jurídicas, distintas a las sociedades de naturaleza mercantil, están normadas por la Ley General sobre Personas Jurídicas sin Fines de Lucro, Ley No. 147, Publicada en La Gaceta, Diario Oficial No.102 de 29 de Mayo de 1992.

Las asociaciones, incluso las de utilidad pública, pueden desarrollar una actividad empresarial. Por lo general, esa actividad es marginal; pero puede suceder que el ejercicio de la actividad empresarial se realice de modo principal o aun exclusivo. Esta circunstancia no modifica la naturaleza de la asociación misma, siempre que se realice con carácter instrumental respecto de los fines de la asociación. No es incompatible con la asociación la obtención de beneficios; lo que la Ley prohíbe es que esos beneficios, una vez obtenidos, se repartan entre los asociados en lugar de destinarse a los fines de la asociación.

Si esa instrumentalidad no existe, es decir, si los resultados de la actividad empresarial no se dedican exclusivamente al cumplimiento de los fines de la asociación, sino que se reparten, directa o indirectamente, entre los asociados, la originaria asociación se habrá convertido en sociedad irregular. Cuando una asociación ejercita una actividad empresarial con carácter instrumental respecto de sus fines adquiere por este mero hecho la condición de empresario, y ello incluso en el caso de que la actividad empresarial que desarrolla sea secundaria o accesoria. Cualquier asociación que ejercite una actividad empresarial adquiere, como cualquier otra persona física o jurídica que así actúe, carácter de sujeto mercantil ${ }^{24}$.

También las fundaciones - organizaciones sin ánimo de lucro cuyo patrimonio está afecto de modo duradero a la realización de los fines de interés general fijados por el fundador- pueden ejercitar una actividad empresarial con carácter instrumental respecto de dichos fines, y en ese caso adquirirán la condición de empresario. La fundación puede ser titular de establecimientos o empresas comerciales, industriales o de servicios por figurar éstos en la dotación fundacional -la dotación puede consistir en bienes y derechos de cualquier clase o por adquirirlos a lo largo de la existencia del ente, y puede ejercitar con ellos actividades mercantiles ${ }^{25}$.

24 ROJO, ob. cit. Pág. 93.

25 Idem. Pág. 94. 


\section{Concepto de empresa (y sus diferentes manifestaciones)}

La empresa es un conjunto organizado de elementos (capital y trabajo) destinado a la producción para el mercado, que en forma generalizada irrumpe tardíamente en el mundo de la economía (aproximadamente con la Revolución Industrial), lo que explica que muchos de los códigos de comercios de países modernos y en desarrollo no la definan ni regulen adecuadamente ${ }^{26}$.

No obstante, de haber irrumpido el término empresa tardíamente, y que en un primer plano nuestro Código de Comercio se refiera al comercio como actividad llevada a cabo por el comerciante, nuestro Código de Comercio menciona la empresa (como sujeto al cual se le aplican normas mercantiles) en más de ochenta ocasiones, además el Código de Comercio al hacer referencia a la quiebra de las sociedades mercantiles nos brinda pinceladas sobre el hecho de que pueda la empresa ser objeto de transmisión con independencia de la sociedad que ostenta su dominio, esto lo vemos claramente expresado en su artículo 1125 " $E l$ convenio en la quiebra de las sociedades anónimas que no se hallen en liquidación, podrá tener por objeto la continuación o el traspaso de la empresa con las condiciones que se fijen en el mismo contrato". De la misma manera, otras leyes de nuestro ordenamiento jurídico como la Ley de Competencia, la Ley de Telecomunicaciones, la Ley de Equidad Fiscal, también la regulan, siendo en nuestra realidad económica y jurídica actual un elemento preponderante más aun cuando ésta es la que es objeto de tráfico económico y jurídico.

Por extraño que parezca, esa realidad económica que es la empresa no está conceptualizada inequívoca y comprensiblemente, ni regulada unitaria y sistemáticamente por el ordenamiento jurídico. La única definición con la que cuenta nuestro ordenamiento -la cual no es completamente concentradora de todas las expectativas que sobre esta noción acarrea cualquier acercamiento jurídico mercantil- es la determinada en el Código del Trabajo artículo 12 "Se entiende por empresa la unidad económica de producción, distribución y comercialización de bienes y servicios. Se consideran como parte de la empresa los establecimientos, sucursales creadas para el crecimiento y extensión de sus actividades siempre que no constituyan una persona jurídica diferente". Esta noción es más económica que jurídica. 
Tampoco existe en el Derecho Mercantil un concepto jurídico de empresa unívoco. Sucede que el Derecho positivo, anclado en categorías jurídicas del pasado histórico y carente de una idónea para reconocer, abarcar e integrar unitariamente la realidad económica, plural y compleja, de la empresa, descompone y escinde la unidad básica de ésta a la hora de regular sus distintas dimensiones, aspectos organizativos y situaciones jurídicas relevante con la perdida consiguiente de la unidad y comprensividad sistemática que debe presidir el ordenamiento jurídico ${ }^{27}$.

\subsection{Concepto económico}

La empresa se configura, en las modernas economías de mercado, como el sistema modelo para ejercitar las libertades económicas de producción e intermediación de bienes y servicios para el mercado, en otras palabras, como "el sistema de organización del ejercicio profesional de la actividad económica en el mercado" 28 .

La empresa es, en su esencia natural, una realidad económica y, en su explicación racional y lógica, un concepto económico. Desde un punto de vista económico, la empresa es una organización de capital y de trabajo destinada a la producción o a la mediación de bienes o de servicios para el mercado con el fin de generar ganancias ${ }^{29}$.

\subsection{Concepto jurídico}

Cuando los juristas han intentado darle a la empresa una definición jurídica, se han encontrado con tres planteamientos:

1. La primera la configuran los que afirman la imposibilidad de obtener un concepto jurídico de empresa que posea contornos precisos.

2. La segunda quienes niegan la posibilidad de obtener un concepto jurídico de empresa que sea unitario y, por tanto, válido para todas las disciplinas jurídicas.

3. La tercera quienes formulan y postulan un concepto jurídico de empresa distinto del económico. Y así, en aplicación de estas dos últimas posiciones doctrinales, se afirma que la empresa es para el Derecho Laboral "comunidad de trabajo o de actividades"; para el

27 JIMENEZ, ob. cit. Pág. 67.

28 FONT GALAN, "La empresa como objeto de negocios jurídicos", en Derecho Mercantil, V I, 54.

29 Idem. Pag. 57. 
Derecho Mercantil "actividad económica del empresario, organizada y profesionalmente dirigida al mercado”; y, para el Derecho de la economía simple "organización productiva”.

Ante esta cuestión la doctrina ha elaborado cuatro respuestas o teorías. Una atomista en virtud de la cual la empresa es una simple pluralidad de elementos privados de unidad jurídica, cada uno de los cuales mantiene su individualidad. Una Unitaria, según la cual la empresa es una unidad integral que sustituye a la diversidad o individualidad de los elementos que la integran. Otros autores han definido una concepción espiritualista de la empresa equiparándola a un bien inmaterial resultante de la actividad empresarial. Una última posición, intermedia, por la cual se afirma que la empresa es una simple unidad funcional, a la que las partes, e incluso el ordenamiento positivo, en ocasiones consideran como si fuera una unidad, especialmente cuando sobre ella se estipulan negocios jurídicos ${ }^{30}$.

Esta última parece ser la solución correcta en nuestro Derecho positivo, por las razones siguientes:

En primer lugar, porque la empresa no puede ser objeto susceptible de soportar derechos reales diversos de los que puedan constituirse sobre cada uno de los diversos elementos que la integran. A estos efectos, la empresa no es un todo, una cosa o una res.

En segundo lugar, porque nada se opone en nuestro derecho vigente a que las partes de un contrato que tengan por objeto la transmisión de la empresa, la consideren unitariamente al estipularlo. Lo cual significa que un único negocio (compraventa, arrendamiento, etc.), generará la obligación de transmitir todos y cada uno de los elementos esenciales. En tercer lugar, porque al cumplirse la obligación de entrega, la empresa no se transmitirá como un todo (de una sola vez o "uno actu"), sino que, por el contrario, se transmitirá individualmente cada uno de sus elementos, respetándose necesariamente la especial ley de circulación privativa a cada uno de ellos (inmuebles según la ley aplicable, igual los muebles, las patentes, marcas según su ley, etc.) ${ }^{31}$.

30 BROSETA, ob. cit. Pág 82.

31 Idem. Pág. 84. 


\section{Reuista de Derecho}

Es un difícil reto del progresivo proceso de juridificación de la empresa que aspira a un estatuto propio para ésta en el que se hace menester: 1) evitar toda escisión de los aspectos subjetivos (empresario y actividad, objetivos (establecimiento mercantil), prestacionales (bienes y servicios producidos), e incluso la fragmentación de la regulación de los distintos grupos de intereses en juego, funciones...; 2) integrar y adecuar la combinación de todos sus aspectos y dimensiones modelo jurídicoconstitucional de empresa a que ha de inspirar el concepto amplio o político jurídico de la empresa (supraconcepto); 3) delimitar y regular jurídicamente el establecimiento ${ }^{32}$ mercantil como objeto patrimonial organizado e instrumento primordial de la actividad empresarial ${ }^{33}$.

En suma, desde un punto de vista estrictamente jurídico patrimonial, la empresa se habrá de concebir como una específica modalidad de "riqueza" productiva, constitutiva de un bien o valor patrimonial de explotación, resultante de la materialización de la iniciativa creadora del empresario, de la proyección patrimonial de su labor organizadora de los distintos factores productivos, facultades, "poderes" y técnicas jurídicas, de la actividad de producción e intermediación de bienes y servicios para el mercado a través del establecimiento mercantil. Este valor patrimonial de explotación se sustenta en tres soportes fundamentales: el empresario (sujeto organizador), el establecimiento (objeto organizado) y la organización ${ }^{34}$.

Parece necesario concluir, que aunque al Derecho le corresponde contar con respuestas normativas que definan y regulen este sistema de organización productiva, la mayoría de legislaciones, inclusive la nuestra, han fracasado en este intento. No obstante, consuela el hecho de que constitucionalmente esté reconocida "la libertad de empresa, de organización de ésta y de iniciativa económica”, lo que brinda al legislador nicaragüense la oportunidad de que en un futuro utilice adecuadamente el término de empresa y empresario al elaborar categorías jurídicas aplicables a estas realidades, y de esta manera los conceptos limitados de "comercio" y "comerciante" dejen de ser imperantes en nuestro ordenamiento.

32 Se distingue la empresa del establecimiento mercantil, la empresa, se dice, es un modo de actividad, y el establecimiento mercantil el instrumento al servicio de la actividad.

33 JIMENEZ, ob. cit. Pág. 67.

34 FONT GALAN, ob. cit. Pág. 72. 


\section{Revista de ODerecho}

Una vez definida la empresa y distinguida de su titular el empresario, vale la pena pasar a desarrollar un elemento importante de ésta los elementos patrimoniales de la empresa, de singular importancia para hacer frente a las obligaciones que la componen y dotarla de valor económico que la haga apetecible para el tráfico jurídico-económico.

\section{El ámbito patrimonial de la empresa}

El patrimonio, en la generalidad de definiciones reconocidas por la doctrina, es conceptualizado como conjunto de bienes de que es titular una persona en un momento determinado. Jurídicamente, es el conjunto de relaciones jurídicas activas y pasivas pertenecientes a una persona que poseen un valor económico ${ }^{35}$. En esencia, el patrimonio es el conjunto constituido por el activo (bienes y derechos) y el pasivo exigible (obligaciones) de una persona o institución.

El patrimonio es cualidad de la persona, por lo que se afirma que sólo las personas tienen patrimonio y que no hay patrimonio sin persona. A cada persona se corresponde un patrimonio: el patrimonio es el atributo más dinámico de la persona.

Anteriormente se afirmó que, el patrimonio contiene 'los derechos y los bienes de una persona'; no obstante, como expresa el Prof. Gerardo González, afirmar esto es inexacto; el patrimonio no contiene, hablando con propiedad, las cosas de que es propietaria una persona, sino los derechos de que esa persona es titular, sobre todo los derechos de propiedad sobre las cosas. Así pues, el patrimonio contiene todos los derechos de la persona: derechos reales (singularmente derechos de propiedad), derechos personales, derechos (sobre bienes inmateriales) intelectuales ${ }^{36}$.

Manifestado a priori que, la esfera patrimonial constituye una proyección de la persona en el sistema económico, un ámbito de poder inherente a toda persona y necesario para la realización de sus fines. Y aunque se afirma que a las personas sólo les corresponde un patrimonio, ello no obsta a que ese patrimonio esté constituido por más de una empresa, y que cada empresa sea una organización de un patrimonio cuyo titular es un sujeto, el empresario, cuya actividad económica está dirigida a la prestación de bienes y servicios para el mercado.

35 DÍEZ PICAZO, Sistema de Derecho Civil, 1978, 28.

36 GONZÁLEZ RIEGA, Ponencia sobre derecho patrimonial civil, abril 2008. 


\section{Revisla de Derecho}

1. Importancia del patrimonio empresarial en el desarrollo de la actividad empresarial

Ya se dijo que toda persona tiene un patrimonio, y no existe patrimonio sin persona. Por lo cual siendo la empresa una específica modalidad de "riqueza" productiva, constitutiva de un bien o valor patrimonial de explotación, cada empresa deberá contar con un elemento objetivo para la realización de su actividad económica, esto es el patrimonio.

Todo el patrimonio de las sociedades comerciales y el conjunto de bienes en las personas físicas (como titulares de las empresas), destinados al ejercicio de una determinada empresa mercantil, es decir todo aquello que en una contabilidad se llama capital fijo o circulante (inmuebles, muebles, mercancías, materias primas, dinero, títulos de crédito, instalaciones industriales, patentes, crédito, derechos de autor, marcas, nombre comercial, emblemas, concesiones gubernativas, participaciones en otras sociedades, etc.), incluye todo aquello que tiene un contenido económico convertible en dinero.

Ese patrimonio será garantía del tráfico económico, es lo que se llama responsabilidad patrimonial universal, en las relaciones jurídicas y en el plano extracontractual. Siempre el empresario deberá contar con un patrimonio que responda de todas sus obligaciones, y por qué no, con el cual éste también pueda traficar. Su titularidad habrá de asegurar las facultades jurídicas, congruentes con la actividad empresarial a la que se destinan. Normalmente, en el orden patrimonial, suponen facultades o poderes de disposición sobre los bienes y elementos patrimoniales.

\section{2. ¿Cómo se integra el patrimonio empresarial?}

La empresa es un conjunto de elementos de variada condición y naturaleza, que, debidamente organizados, posee como finalidad la explotación de una determinada actividad económica ${ }^{37}$. Cada uno de los cuales está sometido al régimen jurídico propio de esa naturaleza, pero alguno de esos elementos están sujetos a una normativa específica, precisamente por su integración dentro del conjunto organizado que es la empresa ${ }^{38}$.

37 BROSETA, ob. cit. Pág. 83.

38 BERCOVITZ, ob. cit. Pág. 215. 


\section{Revista de ODerecho}

Los elementos personales (trabajo), materiales e inmateriales (capital real) que la integran están estrechamente unidos por la organización y por la finalidad económica, existiendo entre ellos una interdependencia funcional. Más estos elementos son de muy variada naturaleza, de la empresa forman parte relaciones laborales cuyo régimen no corresponde al Derecho Mercantil, sino al laboral ${ }^{39}$. En la empresa existen cosas materiales muebles e inmuebles cuyo régimen corresponde al Derecho Civil. En ella existen ciertos derechos de propiedad industrial que como las patentes, modelos de utilidad, marcas, etc., están sometidos al Derecho Mercantil.

Pero la empresa no es un conjunto inerte o inorgánico de todos estos elementos. Es, por el contrario, una unidad funcional y organizada en funcionamiento dotada de vida propia. Es, fundamentalmente, organización productiva de todos aquellos elementos ${ }^{40}$.

\subsection{Concepto de bienes}

A falta de una regulación propia de lo que son los bienes en materia mercantil recurrimos a lo que sobre bienes norma complementariamente el Código Civil nicaragüense. Éste establece en su Libro II, Primer Título, lo concerniente a la propiedad, específicamente los bienes considerados en si mismo. Las cosas en cuanto procuran o sirven para procurar beneficios a las personas, se llaman bienes ${ }^{41}$; los bienes consisten en cosas que jurídicamente son muebles o inmuebles ${ }^{42}$. Las cosas muebles se dividen en fungibles y no fungibles. También se dividen en consumibles ${ }^{43}$.

La cosa, doctrinalmente, comprende todo lo que existe, de manera corporal e incorporal, natural o artificial, real o abstracta ${ }^{44}$, es considerada fuera de toda idea de apropiación. En cambio los bienes son objetos materiales, susceptibles de apropiación, son cosas a las que los hombres le otorgan alguna utilidad y de las cuales éstos se sirven. Siendo la cosa el género, y el bien la especie.

39 Pero hay facetas del régimen de esos elementos personales que es específica del Derecho Mercantil, la que hace referencia a los colaboradores del empresario. BERCOVITZ RODRÍGUEZ-CANO, Apuntes de Derecho Mercantil, 2002, 216.

40 BROSETA, ob. cit. Pág. 83-84.

41 Artículo $596 \mathrm{C}$.

42 Artículo $597 \mathrm{C}$.

43 Artículo $607 \mathrm{C}$.

44 CABANELLAS DE TORRES, Diccionario Jurídico Elemental, 2001,99. 


\section{Revista de Derecho}

$\mathrm{Al}$ respecto, se debe reafirmar que el concepto de bien comprende todos los objetos valiosos, materiales e inmateriales. Un bien sólo tiene tal condición cuando, de algún modo, puede ser influido, dominado y apropiado por el hombre. Así, no son bienes aquellos entes que, según la realidad física, están fuera de nuestro alcance (el sol, las nueves); ni los que no son apropiables en sí, por constituir un modo de bien común de la humanidad (espacio aéreo, sonidos, ideas vulgares, luz) ${ }^{45}$.

La propiedad es el derecho de gozar y disponer de una cosa, sin más obligaciones que las establecidas por las leyes ${ }^{46}$. El derecho de propiedad sobre los bienes permite el uso de los mismos, su disfrute y su disponibilidad. Los derechos patrimoniales pueden ser oponibles erga omnes u oponibles sólo contra persona determinada. Los primeros son reconocidos como derechos reales, los segundos como derechos personales ${ }^{47}$.

Habiendo ya dilucidado lo que para nuestro ordenamiento son bienes, y los derechos de propiedad que sobre esos bienes pueden ejercerse, nos queda, en el marco de la presente investigación, determinar y diferenciar los tipos de bienes en los que está compuesto el patrimonio de la empresa, para a posteriori, pasar a desarrollar de qué manera estos bienes son susceptibles de desplazamiento patrimonial.

2.1.1. Derechos reales

Los derechos reales consisten en derechos subjetivos por los cuales, un sujeto que ostenta la titularidad (atribuibilidad) sobre un bien, pueda exigir de todos los demás sujetos sociales, una abstención a interferir en el disfrute de las ventajas que el bien le reportan ${ }^{48}$.

Se ha configurado a la empresa como una organización de elementos de distinta naturaleza, cuyo titular es el empresario. Esos elementos suelen

45 LACRUZ BERDEJO, Nociones de Derecho Civil Patrimonial e introducción al Derecho, 1992, 119.

46 Artículo $615 \mathrm{C}$.

47 Aun cuando dicha distinción es criticada pues se dice que todos los derechos en si son personales, pues son ejercidos por su titular una persona. Al respecto, es necesario señalar lo afimado por DÍEZ PICAZO, quien manifiesta que la distinción de los derechos patrimoniales debe ser, cuando menos doble y hacerse atendiendo a dos criterios: el de la eficacia, que permite distinguir entre derechos reales y derechos no reales, y el de la función económica que cumplen la estructura del poder que otorgan a su titular, que permite distinguir entre los derechos de disfrute frente a los derechos de obligación. DÍEZ PICAZO, Fundamentos del Derecho Civil Patrimonial, T.I, 1996, 71.

48 GUZMÁN GARCÍA, Apuntes de derecho de cosas, 2008, 11. 


\section{Revista de ODerecho}

dividirse en objetivos y subjetivos. Dentro de los elementos objetivos nos encontramos con distintos bienes que pueden ser de naturaleza corporal o incorporal (material e inmaterial). Pero alguno de esos elementos están sujetos a una normativa específica, precisamente por su integración dentro del conjunto organizado que es la empresa.

Entre los elementos materiales e inmateriales los hay de todas clases y naturaleza, bienes muebles entre los que se encuentran las materias primas y las mercaderías, bienes inmuebles -principalmente el establecimiento principal ${ }^{49}$-, derechos de diversas clases, dinero, valores y títulos valores, derechos de propiedad industrial e intelectual, etc. Cada uno de esos bienes o derechos está sujeto al régimen que le es aplicable según su naturaleza jurídica ${ }^{50}$.

\section{a) El establecimiento mercantil}

Según Cabanellas en Derecho Mercantil, el establecimiento es considerado como casa de comercio, tienda olugardondelos comerciantes desenvuelven sus actividades características ${ }^{5}$. No obstante, para Ángel Rojo, en sentido jurídico, establecimiento mercantil significa el conjunto de elementos materiales y personales organizados por el empresario individual o por la sociedad mercantil para el ejercicio de una o de varias actividades empresariales. Desde esta perspectiva, establecimiento equivale a empresa en sentido objetivo. Habiendo expuesto esto, Rojo ${ }^{52}$ llega a la conclusión que el establecimiento mercantil es el medio o instrumento mediante el cual el empresario ejercita la actividad empresarial ${ }^{53}$.

No obstante, para la autora de la presente investigación, establecimiento mercantil equivale al lugar físico o local donde el empresario desarrolla

49 Consideración propia de la autora, no de Bercovitz, el concebir al establecimiento mercantil como bien inmueble, ya que otros autores equiparan al establecimiento mercantil con la empresa en si.

50 BERCOVITZ, ob. cit. Pág. 216.

51 CABANELLAS, ob. cit. Pág. 152.

52 ROJO, ob. cit. Pág. 101.

53 De la misma manera lo establece Ribo Durán, que el Establecimiento Mercantil, denominado también establecimiento comercial, establecimiento industrial, casa de comercio, negocio, tienda o industria, es término equivalente al de empresa en el sentido organicista o de suma de elementos organizados; pero si se conceptúa la empresa como el resultado de la actividad empresarial, el establecimiento es el instrumento básico de aquélla, o conjunto de elementos materiales e inmateriales que utiliza el empresario para su actividad. RIBÓ DURÁN, Diccionario de Derecho Empresarial, 1998, 115. 


\section{Revista de Derecho}

su actividad empresarial, esto lejos de cualquier equiparación con la empresa, pues el establecimiento, como al final bien lo establece Rojo, es un instrumento de la empresa, o bien uno más de sus elementos susceptible de desplazamiento patrimonial individualmente o en conjunto con la empresa.

El empresario es libre de decidir el número de establecimientos en los que ejercitar la actividad empresarial; el empresario es libre, además, para decidir los elementos que destina al establecimiento y el título jurídico en virtud del cual dispone de ellos. A este respecto cabe recordar que se denominan sucursales aquellos establecimientos secundarios a través de los cuales el empresario individual o la sociedad mercantil ejercitan la misma actividad que la ejercitada a través del establecimiento principal ${ }^{54}$.

De la sucursal se distinguen los locales e instalaciones accesorias en las que se realizan actividades preparatorias o complementarias de la actividad principal. De la sucursal también se distinguen las filiales, mientras que la sucursal es un establecimiento secundario, la filial es una sociedad dedicada a la misma o a distinta actividad que otra sociedad, la cual ostenta la totalidad o, al menos, la mayor parte de las acciones o de las participaciones en que se divide el capital de aquélla, la filial es una persona jurídica, esto es, un ente jurídicamente autónomo ${ }^{55}$.

Habida cuenta de que establecimiento es el lugar o local donde el empresario desarrolla su actividad empresarial, generalmente el establecimiento principal es al que la ley atribuye el domicilio del empresario, entendiendo como tal el lugar donde está establecido, esto es, donde tiene su establecimiento como centro de operaciones comerciales. Así queda establecido por el Código de Procedimiento Civil en su artículo 282 "El domicilio legal de los comerciantes en todo lo que concierne a actos o contratos mercantiles y a sus consecuencias, será el lugar en donde tuvieren el centro de sus operaciones comerciales. Los que tuvieren establecimientos mercantiles a su cargo en diferentes

54 En igual sentido opina BERCOVITZ, "El establecimiento principal es el domicilio del empresario en normalidad de circunstancias donde está el centro de la efectiva administración o dirección. Un empresario, sin embargo, puede desarrollar su actividad empresarial en distintos lugares. Si en esos distintos centros de operaciones, se realizan negocios con terceras personas, entonces a esos centros de actividad empresarial de les denomina sucursales, la cual es todo establecimiento secundario dotado de representación personal y de cierta autonomía de gestión, a través del cual se desarrollen, total o parcialmente la actividades de la sociedad.” BERCOVITZ, ob. cit. Pág. 215.

55 ROJO, ob. cit. Pág. 102-103. 


\section{Revista de Derecho}

circunscripciones judiciales, podrán ser demandados por acciones personales en aquel en que tuvieren su principal establecimiento, o en el que se hubieren obligado, a elección del demandante”.

b) Derechos inmateriales (marcas, patentes, nombre comercial, etc.)

Como se expresó, a priori, el patrimonio de la empresa está constituido por bienes materiales e inmateriales. Dentro de los segundos nos encontramos con todos aquellos que no son susceptibles de corporalidad y que constituyen en sí derechos, derechos doctrinalmente denominados de propiedad industrial.

La misma denominación de «propiedad industrial» que algunos autores censuran por inadecuada, implica ya la adopción de postura sobre la naturaleza jurídica de las distintas figuras que la integran. Esa denominación presupone, en efecto, que los derechos sobre la marca, las patentes y los demás elementos que se incluyen en la categoría, ya sea como signos distintivos o como creaciones intelectuales susceptibles de explotación comercial, representan para su titular auténticos derechos reales, puesto que se emplea para identificarlos el mismo vocablo con que se designa al derecho real por excelencia: la propiedad ${ }^{56}$. Constituyen una parte fundamental de los bienes que son objeto de tráfico económico en la actualidad, los que se negocian y son objeto de explotación generalmente en el ámbito del mercado tecnológico.

Pueden considerarse como bienes inmateriales las ideas o elementos ilimitadamente reproducibles. Caben destacar los derechos de propiedad industrial, que otorgan derechos exclusivos de explotación sobre las invenciones industriales, las marcas y otros signos distintivos de la empresa, y también los derechos de exclusiva que otorga la explotación de la propiedad intelectual, estos derechos son atribuidos al titular del bien inmaterial y le permiten la transmisión de su derecho ${ }^{57}$.

Las patentes considerada como derecho exclusivo reconocido por el Estado, con respecto a una invención cuyos efectos y alcances están determinados poresta Ley, son susceptiblededesplazamientopatrimonial -no la autoría de la patente en sí, pues es un derecho personalísimo-

56 PÉREZ DE LA CRUZ, La propiedad industrial e intelectual (I) teoría general, en Curso de Derecho Mercantil I, 2001, 356.

57 BERCOVITZ, ob. cit. Pág. 141. 
según queda determinado por el artículo 49 de la Ley de Patentes de Invención, Modelos de Utilidad y Diseños Industriales, "transferencia de la patente". "Una patente o una solicitud de patente podrá ser cedida a una persona natural o jurídica en las formas reconocidas por la ley. Toda cesión relativa a una patente o una solicitud de patente deberá constar por escrito. La cesión tendrá efectos legales frente a terceros desde su presentación e inscripción en el Registro de la Propiedad Intelectual...", además puede ser susceptible de licencias contractuales de explotación ${ }^{58}$.

En cuanto a las marcas en su aproximación legal constituyen cualquier signo que sea apto para distinguir productos o servicios ${ }^{59}$. Los derechos sobre las mismas, estén registradas o en trámite de registro, pueden ser transferidos por acto entre vivos o por vía sucesoria, o dichas marcas pueden ser objeto de licencias de uso. La transferencia debe constar por escrito. Para que la transferencia surta efectos frente a terceros, la misma deberá inscribirse ante el Registro y dicha inscripción devengará la tasa establecida ${ }^{60}$.

La Ley de Marcas es la disposición legal que se aproxima en mayor grado a la figura de la transferencia empresarial en nuestra legislación ya que el artículo 31 de ésta establece que la transferencia libre de la marca es "El derecho sobre una marca podrá transferirse independientemente de la empresa o de la parte de la empresa del titular del derecho, y con respecto a uno, algunos o todos los productos o servicios para los cuales está inscrita la marca...”. Nuestra legislación, aunque superficialmente, tipifica la transferencia de la empresa, y segundo que la marca puede transmitirse independientemente o en conjunto con la empresa.

El nombre comercial, como medio de individualización de la empresa, también es susceptible de desplazamiento patrimonial, pero es lógico

58 Ley de Patentes de Invención, Modelos de Utilidad y Diseños Industriales, Ley 354, Publicada en La Gaceta, Diario Oficial, con fechas 22 y 25 de septiembre del 2000. Arto. 50.- Licencias Contractuales. El titular o el solicitante de una patente podrá conceder licencia para la explotación de la invención, la que tendrá efectos legales frente a terceros desde su presentación e inscripción en el Registro de la Propiedad Intelectual. La petición de inscripción de una licencia causará la tasa establecida.

$59 \mathrm{Al}$ respecto, PÉREZ DE LA CRUZ afirma Podemos definir la marca como el signo distintivo que sirve para diferenciar en el tráfico mercantil bienes o servicios procedentes de un empresario o grupo de empresarios de otros bienes o servicios, idénticos o similares, procedentes de los demás empresarios. PÉREZ DE LA CRUZ, ob. cit. Pág. 360.

60 Artículo 30 de la Ley No. 380 "Ley de marcas y otros signos distintivos", Publicada en La Gaceta, Diario Oficial No. 70 del 16 de Abril del 2001. 
que éste únicamente pueda transmitirse con la totalidad de la empresa, ya que siendo un signo de distinción de un negocio o empresa mercantil, no es concebible que este elemento que identifica en el comercio, ante la clientela, a una empresa como organización pueda transmitirse sin que eso lleve consigo la empresa. Así queda reflejado y determinado por la Ley de Marcas en su artículo 65 in fine, sobre la transferencia del nombre comercial nos dice que "solo puede transferirse junto con la empresa o el establecimiento que lo emplea, o con aquella parte de la empresa o del establecimiento que lo emplea.”.

De lo anterior, se puede concluir que las diversas modalidades que integran la propiedad industrial son transmisibles por todos los medios que el derecho reconoce, pero su transmisión no producirá efectos frente a terceros mientras no se acredite en registro mediante documento fehaciente.

Son por tanto transmisibles el nombre comercial, los rótulos y las marcas, etc., tanto inter vivos como mortis causa. Vale recalcar que el nombre comercial únicamente puede transmitirse con la empresa, en cambio los rótulos y las marcas pueden transmitirse separadamente.

Referente a las patentes, el inventor es titular de varios derechos y soporta diversas obligaciones, el derecho a ser considerado y reconocido autor del invento es personalísimo e intransferible, posee además el derecho patrimonial a explotar en exclusiva la invención, derecho que total o parcialmente puede ceder a terceros mediante la concesión de las correspondientes licencias de explotación.

\section{c) Otros}

\section{c.1. Mercaderías}

Otros de los bienes que constituyen parte del patrimonio del empresario lo constituyen las mercaderías, que constituyen, en el ámbito comercial o industrial $-\mathrm{y}$ también contablemente-, el inventario, en el que generalmente centra el objeto de actividad económica la empresa. Éstas son consideradas como cosas muebles objetos de tráfico mercantil, o sea, objeto de actividades lucrativas más o menos directas, entre productores y fabricantes, y otros comerciantes o el público en general. 


\section{Revista de ODerecho}

La regulación del Derecho Mercantil tradicional a lo largo de la historia se centró en torno a la compraventa de mercaderías, sin embargo el comercio de mercadería es solamente una parte del tráfico económico en el mercado. La noción de mercadería, como objeto del tráfico económico en el mercado, tiene pues una gran importancia para la compraventa mercantil. Las mercaderías son bienes muebles corporales con valor ínsito en ellos mismos y que están en la actualidad en el tráfico económico. Se trata pues de bienes muebles; con lo que se excluye de las mercaderías a los bienes inmuebles. Se trata de bienes muebles materiales, que como tales se distinguen de los derechos que tienen la consideración de bienes muebles y se distinguen también de los bienes inmateriales, que aunque son bienes muebles, carecen de copropiedad.

Las mercaderías son bienes muebles corporales con valor ínsito en ellos mismos, lo que sirve para diferenciarla de los títulos valores, que también son muebles, pero se trata de documentos cuyo valor no radica en el papel mismo que integra el bien corporal, sino el derecho inmaterial que se incorpora al documento ${ }^{61}$.

\section{c.1.1. Fondo de comercio}

Algunos autores distinguen dentro de la empresa un elemento de esencia particularmente especial denominado hacienda o fondo de comercio, el cual en sí está constituido por los bienes y derechos que la empresa usa como instrumental y que constituye el elemento objetivo de ella. Constituyen los elementos patrimoniales y las relaciones jurídicas que se requieren para la consecución del fin de la empresa, que el propio empresario organiza.

La expresión "hacienda" abarca, según la doctrina italiana, todo el patrimonio de las sociedades comerciales y el conjunto de bienes en las personas físicas, destinados al ejercicio de una determinada empresa mercantil, es decir todo aquello que en una contabilidad se llama capital fijo o circulante (inmuebles, muebles, mercancías, materias primas, dinero, títulos de crédito, instalaciones industriales, patentes, crédito, derechos de autor, marcas, nombre comercial, emblemas, concesiones gubernativas, participaciones en otras sociedades, etc.), contiene todo aquello que tiene un contenido económico convertible en dinero. No obstante, los conceptos de empresa y hacienda se diferencian, ya que la

61 BERCOVITZ, ob. cit. Pág. 135. 
empresa en su aspecto funcional está definida como la organización del trabajo y los factores de la producción mediante la cual se desarrolla la actividad profesional del empresario. La hacienda en cambio solo es el conjunto de bienes organizados por el empresario para el ejercicio de la empresa $^{62}$.

En cambio para otros, el fondo de comercio tiene otra significación que va más allá de lo meramente material, constituyendo uno de los elementos inmateriales integrantes de la empresa, conformado por la clientela y las expectativas negociales; es decir, el activo inmaterial, que no puede ser utilizado sin cesión de ésta ${ }^{63}$.

En este mismo sentido, Bercovitz expresa que el fondo de comercio hace referencia al mayor valor que tiene el conjunto organizado que es la empresa y que excede de la suma de los valores que corresponden a los elementos patrimoniales que integran la empresa. El fondo de comercio no es, por tanto, ningún elemento autónomo de la empresa sino el valor que está dispuesto a pagar un adquirente de la empresa por la organización empresarial en sí misma considerada tal como está implantada en el mercado, y que excede del valor de los elementos individuales integrados en la empresa.

Es obvio que el fondo de comercio no tiene autonomía, puesto que no es en sí mismo ningún elemento patrimonial, lo cual significa que sólo puede transmitirse junto a la empresa ${ }^{64}$.

Nuestro ordenamiento jurídico no norma de ninguna manera el denominado fondo de comercio como elemento autónomo patrimonial o no de la empresa. Sin embargo, si en algún momento el legislador $\mathrm{u}$ otro decidiera considerar al fondo de comercio como elemento de la empresa, considero y me inclino porque el fondo de comercio sea tratado como elemento inmaterial constituido por las expectativas negociales, clientela, reputación u otros, que dan mayor valor a la empresa en su conjunto, y que en algunos ordenamientos se les permite contablemente cuantificar pecuniariamente éste, dándole mayor valor a la empresa, y que únicamente podrá ser transmitido con la misma.

62 BAUCHE, ob. cit. Pág. 34.

63 FERNÁNDEZ FERNÁNDEZ, Diccionario de Derecho Empresarial, 1998, 411.

64 BERCOVITZ, ob. cit. Pág. 259-260. 


\section{Revisla de Derecho}

c.2. Derechos personales (acciones, cesión de contratos empresariales)

Respecto a los derechos personales, su denominación es tan tradicional como combatida; pues, al no poder existir derecho alguno sin titular, todos son personales. Empero, siguiendo el convencionalismo, se entiende por derecho personal el vínculo jurídico entre dos personas, a diferencia del real, en que predomina la relación entre una persona y una $\operatorname{cosa}^{65}$.

\section{c.2.1. Contratos empresariales}

Relativo a los contratos suscritos por la empresa para la realización de su actividad empresarial, éstos son de naturaleza personal. Las relaciones contractuales de una empresa configuran uno de sus más valiosos elementos. Los negocios transmitidos son los denominados contratos sinalagmáticos, en que las prestaciones aun no hayan sido exigidas. Es evidente, que existen ciertos contratos que no podrán ser transmitidos con la empresa, estos son los que resultan intransmisibles por las cualidades personales del contratado o los afianzados en relaciones de confianza.

El empresario que transmite una empresa es normalmente parte en una pluralidad de contratos estipulados con terceros, contratos que generalmente nacen de la actividad misma de la empresa y que, en ocasiones son indispensables para su explotación e incluso para su propia subsistencia. Este suele ser, por ejemplo, el contrato de arrendamiento de locales de negocios, del de suministro de materias primas y del contrato de licencia de explotación de patentes. La pregunta está si estos contratos se transmiten automáticamente al adquirente. La cesión de un contrato, en términos generales, implica la subrogación de un tercero (en este caso, el adquirente de la empresa) en la posición contractual del cedente (el transmitente) y parece evidente que una modificación de esta naturaleza no puede producirse sin el consentimiento de la otra parte contratante ${ }^{66}$.

Quien adquiere una empresa se subroga en los contratos establecidos por el ejercicio de las actividades propias de aquélla que no tenga

65 GONZÁLEZ RIEGA, ob. cit. abril 2008.

66 BROSETA, ob. cit. Pág. 88. 


\section{Revista de ODerecho}

carácter personal. Empero, por regla general es que el adquirente no se subroga en la posición contractual del transmitente: los contratos no se transmiten con la empresa. La subrogación del adquirente en la posición jurídica del transmitente requiere no sólo la voluntad expresa de éstos, sino también la conformidad de la persona o personas con las que hubiere contratado el titular del establecimiento ${ }^{67}$.

\section{c.2.2. Créditos}

Es evidente que dentro del mercado también circulan y son objeto de negocios los créditos. Créditos, que sin duda, en la mayoría de los casos, constituyen una parte fundamental del patrimonio empresarial.

En relación con los créditos de que sea titular el transmitente, la transmisión del establecimiento no implica la transmisión de esos créditos, no permitiendo presumir la cesión de los créditos frente a terceros de que fuera titular el transmitente, tiene que haber pacto expreso entre los contratantes; y la notificación aunque no es exigida sí es necesaria ${ }^{68}$.

\section{c.2.3. Las acciones}

Las acciones constituyen una parte de la esfera patrimonial no de la empresa sino de la sociedad, debido a que es el patrimonio de la sociedad, en su caso, el que se divide en acciones -no la empresa-. Por tanto al hablarse de transmisión de la empresa en modo directo la transmisión de las acciones no juega ningún rol, ya que si se hablara de transmisión de acciones para adquirir una empresa se estaría pensando en formar parte como nuevo socio de una sociedad, la sociedad continuaría siendo dueña de la empresa y la empresa en ningún modo habría cambiado de titular.

\section{c.2.4. La clientela (elemento particularmente especial)}

La clientela es el conjunto de personas, identificadas individualmente o no, que adquieren los bienes o servicios producidos y ofrecidos por la empresa en el mercado. Sin clientela no puede existir una empresa

67 ROJO, ob. cit. Pág. 119.

68 Idem. Pág. 121. 


\section{Revista de Perecho}

y a través de ella se manifiesta la implantación y el éxito de ésta en el mercado. El reflejo contable de la clientela es el volumen ordinario de negocios de la empresa. Es obvio que la clientela no es un elemento integrante de la empresa, viene a ser la contraparte en los negocios de la empresa en el mercado.

Lo normal es que la clientela sólo se trasmita junto con la empresa o con una parte de ésta a la que la clientela esté vinculada. La lista de clientes de una empresa es un elemento con valor patrimonial y cuya comunicación no autorizada a otros competidores constituye un acto de competencia desleal.

Por otra parte los signos distintivos de la empresa (marcas, nombre comercial, rótulo del establecimiento) sirven para vincular precisamente la clientela a la empresa. Por ello la transmisión de signos distintivos fundamentalmente la marca sirve indirectamente para ceder la clientela que adquiere habitualmente los productos o servicios identificados por ese signo distintivo. Así pues, el principio general consiste en que la clientela no puede transmitirse con independencia de la empresa ${ }^{69}$.

c.3. Obligaciones (responsabilidad por deudas en la transmisión de la empresa en nuestro ordenamiento jurídico)

Existe comúnmente en las empresas un elemento patrimonial cuyo carácter económico, a diferencia de los anteriores, es de signo negativo y que supone en la práctica jurídica de transmisiones de empresas un foco de frecuentes conflictos entre las partes y los terceros acreedores: se trata de las deudas de la empresa contraídas por el empresario cedente. El problema reside, en el fondo, en determinar quién o quiénes asumen, y en qué forma o grado, la responsabilidad de satisfacer tales deudas ${ }^{70}$.

Nuestro Código Civil establece que obligación es la relación jurídica que resulta de la ley o de dos o más voluntades concertadas, por virtud de la cual puede una persona ser compelida por otra a dar alguna cosa, a prestar un servicio o a no hacer algo ${ }^{71}$. En el caso de las obligaciones pecuniarias, constituyen lo que denomina las deudas (o pasivo circulante,

69 BERCOVITZ, ob. cit. Pág. 261-263.

70 FONT GALAN, ob. cit. Pág. 83.

71 Articulo $1830 \mathrm{C}$. 
contablemente hablando, pues es lo más cercano a obligación liquida o liquidable para el empresario) u obligaciones de dar cantidades liquidas o liquidables por parte del empresario.

Cabanellas señala que, deuda trae un efectojurídico necesario equivalente a la prestación que el sujeto pasivo (o deudos) de la relación obligacional debe al sujeto activo (o acreedor) de la misma. Así, toda deuda consiste en un dar, hacer o no hacer algo que el otro puede exigir, y que en su acepción más frecuente y conocida equivale a lo que ha de pagarse en dinero, esté o no vencida la deuda ${ }^{72}$.

En el tema que nos ocupa, al transmitirse la empresa deberá considerarse si con ésta deben transmitirse las deudas, ya que constituyen una parte importante del patrimonio de todas las empresas. Existe transmisión de éstas cuando la obligación pasa de una persona a otra sin que se produzca novación y, como consecuencia, la extinción del vínculo obligatorio y el nacimiento de uno nuevo; la obligación sigue siendo la misma, el mismo acreedor y el mismo objeto. Nuestro Código Civil acepta la cesión de créditos, pero con relación a la cesión de deudas guarda silencio, no la contempla pero tampoco la prohíbe.

Existen dos formas de realizar la asunción de adeudos: a) en virtud de un contrato celebrado entre acreedor y el nuevo deudor, perdiendo aquél su crédito contra el primitivo deudor; b) en virtud de un contrato celebrado entre el deudor y el tercero que asume la deuda, sujeta al consentimiento o ratificación del acreedor que pierde su derecho contra el primitivo deudor, si la ratificación es negada, la asunción de deuda vale como no realizada ${ }^{73}$. Como existe libertad contractual (unido al principio de autonomía de la voluntad) cualquiera de las dos maneras es susceptible de aplicarse en el tráfico jurídico nicaragüense.

Siguiendo este lineamiento, Rojo considera que la transmisión de la empresa no implica la asunción por el adquirente de las deudas que el transmitente hubiera contraído para la organización o el funcionamiento del establecimiento, y que no sólo basta el pacto, además se requiere el consentimiento del acreedor que puede ser simultaneo o posterior a la transmisión de la empresa ${ }^{74}$.

72 CABANELLAS, ob. cit. Pág. 128-129.

73 ESCOBAR FORNOS, Derecho de Obligaciones, 2000, 378.

74 ROJO, ob. cit. Pág. 121. 
En un sentido contrario, Gutiérrez Falla considera que las deudas contraídas por el anterior titular de la empresa, son transmitidas al adquirente, el cual se convierte en obligado directo de todas las deudas incurridas por el empresario tradente en la explotación de la empresa mercantil cedida, aunque éstas predaten a la fecha de la cesión. El autor recomienda que se transcriba en el cuerpo de la escritura un balance general de la empresa vendida, garantizando el vendedor que dicho estado financiero es el reflejo fiel del estado de la empresa transmitida ${ }^{75}$.

Por excepción a libertad de contratación, y con total independencia de lo que hayan pactado las partes, nuestro ordenamiento regula someramente lo que es la transmisión de obligaciones tributarias y laborales cuando esto es producido por el cambio de titular de la empresa.

En el artículo 12 del Código Tributario se establece que "La obligación tributaria es personal e intransferible, excepto en el caso de sucesiones, fusiones, absorciones, liquidaciones de sociedades y de solidaridad tributaria y aquellas retenciones y percepciones pendientes de ser enteradas al Fisco, como casos enunciativos pero no limitativos". No establece clara y expresamente la transmisión directa de las empresas por acto entre vivos, pero se puede aplicar este precepto análogamente.

A esto aúna el hecho de que en el artículo 65 de la Ley de Equidad Fiscal, se regule "el traspaso de negocio" mandatando que "En caso de traspaso de negocios, el adquirente deberá exigir constancia de solvencia en relación al IVA. La no presentación de dicha constancia obligará solidariamente al adquirente de los impuestos no enterados por el anterior responsable recaudador"; y en su artículo 136 nuevamente reafirma que "En caso de traspaso de negocios bajo cualquier figura jurídica, el adquirente del mismo, será solidariamente responsable de los impuestos y/o adeudados por el cedente" ${ }^{2}$. Se vislumbra de estas disposiciones, que nuestro legislador previó el traspaso de la empresa -aunque por la variada denominación que legislativa y doctrinalmente identifica la empresa, esta vez el legislador se refiere a la empresa como negocio- y no solamente esto, además hecha de ver que la misma puede transmitirse mediante varias figuras jurídicas, sin llegar a definirlas.

75 GUTIÉRREZ FALLA, ob. cit. Pág. 117.

76 Ley de Equidad Fiscal, Ley No. 453, Publicada en La Gaceta, Diario Oficial No. 82 del 6 de mayo del 2003. 
Lo que si queda claramente establecido es que en caso de traspaso de empresas si los tributos no han sido finiquitados por el anterior propietario convierte en solidariamente responsable al nuevo adquirente de ésta.

En este mismo orden de cosas, nuestro Código del Trabajo manda que "La sustitución del empleador no afecta las relaciones de trabajo. El empleador sustituido será solidariamente responsable con el nuevo, hasta por el término de seis meses, por las obligaciones derivadas de las relaciones de trabajo y de la ley, nacidas antes de la fecha de sustitución, concluido el trabajo subsistirá únicamente la responsabilidad del nuevo empleador ${ }^{77 ”}$. Lo que viene a significar que la transmisión de la empresa no extingue la relación laboral de los trabajadores que presten sus servicios en el establecimiento: el adquirente queda subrogado ope legis en los derechos y obligaciones laborales del anterior titular.

\section{La empresa como objeto de negocios jurídicos}

Conviene advertir que no es posible que algo sea al mismo tiempo sujeto y objeto de derecho. En la empresa existe siempre un sujeto de derecho al cual le es imputable la actividad empresarial, y éste no es la empresa en sí, sino el empresario.

Hablando de la empresa como objeto de negocio jurídico -objeto de derecho-, o sea cuando ésta -entendida como un ente único o universalidad- es objeto de transmisión, debe haber primero un acto unitario sobre el bien empresa y luego, éste se disgrega en una complejidad e interconexión de actos de ejecución de muy distinta naturaleza aptos para construir titularidades de distinto carácter según su objeto, que si se trataran separada y desordenadamente no se conseguiría la finalidad circulatoria del bien conjunto y unitario.

Se diferencian en dos los tipos de transmisión de la empresa: la que se puede dar en forma directa o la que se puede dar en forma indirecta. Se califica de transmisión directa aquella transmisión en la que el objeto del negocio es la empresa o los establecimientos del transmitente; y se habla de transmisión indirecta para hacer referencia a la transmisión de la totalidad de las acciones o de las participaciones en que se divide el capital de una sociedad cuyo patrimonio se encuentra constituido

77 Artículo $11 \mathrm{CT}$. 


\section{Revista de Derecho}

exclusiva o principalmente por uno o varios establecimientos. Mientras que en el primer caso, por virtud de la transmisión, cambia el titular del establecimiento, en el segundo el titular sigue siendo la sociedad, que es la que cambia de manos $^{78}$.

Se debe aclarar que la transmisión de la empresa no implica un caso de fusión o transformación de sociedades, cuyas consecuencias se exteriorizan jurídicamente sobre la sociedad -empresario social- y no directamente sobre la empresa. En el caso de fusión ${ }^{79}$ la sociedad transmitente se disuelve y liquida -y en el caso de fusión por integración la disolución, liquidación y extinción de todas las sociedades fusionadas-, cosa que no ocurre cuando la empresa es objeto directo de negocios jurídicos donde ninguno de los sujetos participantes en el negocio tienden, por objeto del contrato, a desaparecer ${ }^{80}$. Y en el caso de transformación de la sociedad, únicamente un sujeto concurre en este instrumento jurídico a mutar su forma social, no habiendo en ningún momento desplazamiento de patrimonio empresarial.

Se debe concluir, por tanto, que el hecho de que el comerciante social transmita su empresa no significa que deje de existir como tal, ya que: la empresa transmitida puede ser una de las varias empresa de la que es titular la sociedad, o, si la empresa es vendida, la sociedad vendedora percibirá el precio cuyo importe formara parte de su patrimonio que puede invertir en nuevos negocios, no obstante de que si podría significar la modificación de su contrato social, pues el objeto social tendría que cambiar por motivos referentes a la competencia. Así también, la transmisión de la empresa no es causa de disolución de la sociedad transmitente, quien, por tanto, quedará obligada al pago de las deudas en que haya incurrido, que no correspondan a la empresa transmitida. La transmisión de una empresa no debe representar pérdida patrimonial alguna para el tradente, ya que, como sucede en el caso de la compraventa, recibirá como contraprestación del adquirente el valor de la empresa transmitida ${ }^{81}$.

78 ROJO, ob. cit. Pág. 118.

79 Así los presupuestos jurídicos de toda fusión son tres: 1. La extinción de todas o algunas de las sociedades involucradas. 2) la transmisión del patrimonio de las sociedades que desaparecen a la nueva o a la absorbente, según el caso. 3) la integración de los socios de las entidades extinguidas a la sociedad nueva o a la absorbente. HERRERA ESPINOZA, Derecho Mercantil I, 2008, 109.

80 Además la fusión da lugar a la sucesión universal en los derechos y obligaciones de las sociedades que se extinguen por la fusión, por lo que los problemas típicos de la transmisión jurídica en sentido estricto de la empresa desaparecen.

81 ROJO, ob. cit. Pág. 145 y 150. 


\section{Revista de Derecho}

\section{Desplazamiento patrimonial y sus formas}

Algunas legislaciones, como la hondureña y la salvadoreña, consideran a la empresa mercantil una "cosa mercantil", y su traspaso como un "acto de comercio", que abarca tanto la transmisión del dominio y posesión de dicho mueble, sea por actos inter vivos o mortis causa, sino, a su vez, el traspaso de la tenencia de la misma, como sería el caso del arrendamiento y el usufructo.

Así pues, se dice que al transmitir la empresa se transmiten un conjunto unitario de elementos patrimoniales -que junto a la organización y el empresario conforman la empresa-, tales como:

- El establecimiento de la misma,

- La clientela y la fama mercantil,

- El nombre comercial y los demás signos distintivos de la empresa y del establecimiento,

- Los contratos varios,

- El mobiliario y maquinaria, los contratos de trabajo,

- Las mercancías, créditos, y los demás bienes y valores similares

- Las deudas contraídas por el anterior titular.

Sabemos que la empresa posee un valor superior al que resulta a la suma de los valores de sus simples elementos integrantes, lo que hace que frecuentemente la empresa sea transmitida por actos "inter vivos" o "mortis causa"

\subsection{Formas de transmisión inter vivos de la empresa}

Los supuestos de transmisión inter vivos de la empresa se pueden clasificar en dos categorías diferentes: están, de un lado, los casos de transmisión voluntaria, que son la regla, y, de otro, los casos de transmisión forzosa que viene a configurarse como la excepción. La voluntaria puede ser a título oneroso - compraventa, permuta, aportación a sociedad, dación en pago, etc.-, o bien a título gratuito -donación-; y, por su lado, la transmisión forzosa puede producirse como consecuencia de un procedimiento de ejecución individual, o como consecuencia de un procedimiento de ejecución colectiva o de quiebra. 


\section{Revisla de Derecho}

Los supuestos de transmisión de la empresa se distinguen claramente de los supuestos de transmisión individual de los elementos de que se compone, el titular de la empresa puede transmitir aisladamente a una o varias personas tantos elementos considere oportuno, la única excepción que ha de hacerse es la del nombre comercial, que sólo puede transmitirse con la totalidad del establecimiento. No obstante, si los elementos que se transmiten son suficientes para que el adquirente pueda desarrollar con ellos la actividad empresarial, se presumirá que ha existido transmisión de la empresa ${ }^{83}$.

En relación con la transmisión jurídica “inter vivos" de la empresa en sentido estricto hay que partir de dos premisas básicas:

En primer lugar la empresa no está considerada por el ordenamiento jurídico como un único bien con individualidad y régimen de transmisión propia, sino que cada uno de los elementos que la integran están sujetos al régimen de transmisión que le es aplicable según su propia naturaleza jurídica. Así, los bienes inmuebles estarán sujetos a las normas de transmisión de esta clase de bienes; del mismo modo que los bienes muebles o los derechos de propiedad industrial o intelectual se deben transmitir conforme a las disposiciones legales que rigen respectivamente para ellos. Asimismo las deudas y los créditos habrán de sujetarse para su transmisión a lo dispuesto para la cesión de las deudas y de los créditos.

En segundo lugar hay que tener en cuenta que la autonomía jurídica de los elementos integrados en la empresa no impide que el titular de ésta, en la medida que ostenta la titularidad de los distintos elementos que la componen, pueda realizar negocios sobre el conjunto organizado de los mismos que es la empresa. La empresa puede ser, por tanto, objeto de negocios jurídicos de carácter unitario ${ }^{84}$.

Conviene pasar a analizar de manera sucinta cada una de las formas de transmisión jurídica estricta de la empresa, para posteriormente ampliar un poco sobre el contrato de compraventa de empresa, como modalidad especifica de transmisión de la empresa.

83 ROJO, ob. cit. Pág. 118.

84 BERCOVITZ, ob. cit. Pág. 268-269. 


\section{Revista de ODerecho}

\subsubsection{Compraventa de la empresa}

La compraventa es el supuesto más habitual de transmisión inter vivos de la empresa, donde objeto de la compraventa es la empresa en cuanto tal, como conjunto organizado de elementos patrimoniales y personales. Conviene partir, por tanto, de la unidad del título: un único contrato de compraventa, y no una pluralidad de ellos. Por supuesto, para la validez del contrato basta el consentimiento de las partes ya que es contrato consensual y no es menester observar formas especiales ni requisito alguno de publicidad. Y esta afirmación es igualmente aplicable a los demás supuestos de transmisión inter vivos de la empresa (permuta, aportación a la sociedad, dación en pago, usufructo, arrendamiento, etc.).

La voluntad de las partes ha de referirse a un conjunto unitario, de modo que el negocio se transmita en bloque, lo que hace que estemos no ante varios contratos de compraventa de los bienes que componen el negocio y de las relaciones jurídicas o de hecho que están vinculadas al mismo, sino ante un contrato cuyo objeto es único. Problema diverso es que a efecto de la obtención de la titularidad de los elementos que forman el negocio será preciso en ciertos casos utilizar algunos modos de entrega o acudir a ciertas formas para la adquisición de la titularidad necesaria. Es decir, recordando la teoría del título y el modo $^{85}$, hemos de decir que el título de transmisión de la empresa o negocio es único y el modo puede ser diferente para sus distintos elementos.

La unidad del contrato no se rompe por la circunstancia de que se excluyan del objeto del contrato de compraventa determinados elementos del negocio; exclusión que habrá de determinarse por medio de la interpretación de la voluntad de las partes ${ }^{86}$.

$85 \mathrm{Al}$ respecto, la doctrina del título y el modo se basa en una interpretación causalista de la traditio romana. así, la traditio por sí sola no es útil para transmitir el dominio, si no va precedida de un negocio jurídico antecedente, que justifica la transmisión. Es necesaria pues la yuxtaposición de dos elementos que dan lugar a un supuesto complejo de formación sucesiva: el contrato antecedente, al que se le llamará causa remota, iusta causa o titulus; y el traspaso posesorio, que será la causa próxima o el modo de adquirir; la conjunción de ambos elementos determina la transmisión. Si únicamente ha existido titulus o iusta causa, habrá una simple relación con puro valor obligacional; pero no verdadera transmisión de la propiedad. DÍEZ PICAZO, Sistema de Derecho Civil, 2002, 60. 


\section{Revista de Derecho}

\subsubsection{El arrendamiento de la empresa}

El arrendamiento de la empresa se define como aquel negocio jurídico en virtud del cual se cede la explotación de una empresa a persona distinta de su titular, por precio y tiempo determinado ${ }^{87}$.

Constituye una forma temporal y limitada de transmisión, por la cual su titular cede el uso y explotación de la empresa por tiempo determinado y precio cierto. Este contrato suele utilizarse para invertir capitales con el fin de obtener una rentabilidad superior a la que procura la inversión en valores mobiliarios.

Para que exista el arrendamiento de la empresa es preciso que el arrendamiento tenga por objeto el conjunto organizado de bienes susceptibles de ser inmediatamente explotados en el mercado. El arrendamiento no se refiere, pues, a elementos aislados.

Por la naturaleza misma del objeto arrendado (un conjunto de cosas y servicios productivos), el arrendamiento de empresas mercantiles es un arrendamiento especial, muy distinto al arrendamiento de cosas concretas o determinadas que constituye el modelo contemplado por el Código Civil. Éste es completamente atípico en la legislación nicaragüense.

Existirá arrendamiento de la empresa si se cumplen tres requisitos: 1) cuando el objeto arrendado sea un local y el negocio o industria en él instalado; 2) cuando todo ello constituya una unidad patrimonial dotada de vida propia; 3) y, finalmente, cuando la finalidad del arrendamiento sea continuar la explotación de la actividad económica realizada por el arrendador con aquel conjunto organizado, y no iniciar "ex novo" por el arrendatario la explotación de una actividad.

No será, por tanto, arrendamiento de empresa el que tenga por objeto un local con algunos elementos inconexos y desorganizados, ni el que transmita un local con elementos organizados no explotados anteriormente como empresa.

87 FONT GALAN, ob. cit. Pág. 88. 


\section{Revista de Derecho}

El contenido del contrato será:

1. El arrendador debe conferir al arrendatario un poder de disposición sobre las materias primas, enseres y mercancías que sea necesario para transformar o enajenar para explotar la empresa arrendada.

2. El arrendador está obligado a una especial prestación de colaboración al arrendatario, destinada no sólo a entregar en forma útil todos los elementos esenciales de la empresa, sino también a poner a su disposición todo lo que sea necesario para explotarla.

3. El arrendador debe mantener al arrendatario en el goce pacifico de la empresa.

El arrendatario tiene la obligación de:

1. Explotar ${ }^{88}$ la empresa con la diligencia propia de un ordenado comerciante sin cambiar ni alterar su objeto.

2. Restituirla ${ }^{89}$ al término del arrendamiento en el mismo estado en que fue recibida ${ }^{90}$.

El arrendamiento de la empresa pone de manifiesto claramente la distinción entre ésta y el empresario. El empresario no es en este caso el propietario arrendador de la empresa, sino el arrendatario en cuyo nombre se asumen las obligaciones a que da lugar la explotación de la empresa. Precisamente porque el arrendatario no es el propietario o titular de la empresa, ocurre que los elementos integrados en la empresa no responden de las obligaciones asumidas por el arrendatario. De esas obligaciones responde solamente el patrimonio del arrendatario. Este dato es muy importante y debe ser tenido en cuenta por quienes contraten con el empresario, puesto que puede generarse la falsa impresión de que

88 Se debe explotar usando el mismo nombre comercial del dueño, y debe conservar la empresa en el mismo nivel económico y con la misma potencialidad de ganancia con que se la entregó el dueño, lo que entraña no disminuir el valor de su hacienda, ni de su aviamiento objetivo, aplicando una actividad empresarial de magnitud y efectividad. Lo que se transmite al arrendatario es un poder de gestión sobre la empresa que conlleva y le impone una limitada disponibilidad en función de su conservación.

89 Dicho poder de disposición sobre las existencias, una vez ejercitado, transfiere la propiedad de esos bienes directamente del propietario de la empresa al adquirente, sin que el arrendatario haya adquirido jamás la titularidad sobre los mismos. La diferencia en el inventario inicial y final se liquida en dinero y no en mercadería.

90 BROSETA, ob. cit. Pág. 91-92. 


\section{Revista de Derecho}

de sus obligaciones responderán los bienes integrados en la empresa, lo cual no será cierto cuando ésta esté cedida en arrendamiento ${ }^{91}$.

La doctrina mayoritaria considera que no son de aplicación para el arrendamiento las reglas del traspaso de las deudas, es inaceptable, jurídicay comercialmente, que el dueño quedeliberado delas obligaciones que había contraído, porque sólo traspasa el uso y disfrute de la cosa. Por lo anterior, los acreedores del dueño siguen contado con la empresa dada en arrendamiento para procurar la satisfacción de sus créditos, ya que el dominio de la empresa permanece en el patrimonio de su deudor. En igual sentidos, las deudas incurridas por el arrendatario durante su gestión no se transmiten al dueño, una vez terminado el respectivo negocio jurídico ${ }^{92}$.

El contrato se extingue por las causas generales (transcurso del tiempo, mutuo acuerdo, resolución por incumplimiento, en especial por falta de pago del precio, etc.). En el caso de que el ejercicio del negocio origine una situación de insolvencia, suspenderá pagos o quebrará el arrendatario y no el arrendador pues aquél y no éste es el empresario. La quiebra del empresario no afectará a los bienes que forman el negocio que no son de su propiedad, pero dados los efectos que produce la declaración de quiebra sobre el quebrado ha de entenderse que se produce una causa de extinción del contrato de arrendamiento ${ }^{93}$.

\subsubsection{Usufructo de la empresa}

El usufructo de la empresa como contrato de transmisión empresarial, resulta relativamente escaso en el tráfico jurídico, y más aun, el mismo es igualmente atípico en nuestra legislación, de ahí que haya que configurarse y regularse con el apoyo de la normativa general del usufructo.

Es el usufructo un derecho que se constituye sobre una cosa o derecho. Más como la empresa no es una cosa susceptible de soportar unitariamente derechos reales, el usufructo de la empresa será único en su momento constitutivo y se descompondrá en tantas relaciones de usufructo cuantas cosas o bienes compongan la empresa. Según Garrigues, este usufructo comprenderá: un usufructo propio (respecto

91 BERCOVITZ, ob. cit. Pág. 2002, 279.

92 GUTIÉRREZ FALLA, ob. cit. Pág. 190.

93 SÁNCHEZ CALERO, ob. cit. Pág. 196. 
de inmuebles), un usufructo sobre cosas consumibles, un usufructo de disposición (sobre las cosas que deben enajenarse), y un usufructo de derechos $^{94}$.

Admitida la unidad del negocio y su consideración jurídica como universalidad, se hace posible la constitución de un derecho de usufructo sobre él, si bien la falta de una regulación precisa plantea problemas de difícil solución. El usufructuario tiene el derecho de gozar de los beneficios que produzca el negocio y la obligación de conservar su forma y sustancia, lo cual lleva consigo el deber de mantener su explotación, ya que en otro caso el negocio se destruiría. El ejercicio por parte del usufructuario de la actividad empresarial hace que adquiera la condición de empresario mercantil (que pierde el nudo propietario). Como en el caso del arrendatario, tendrá la facultad de enajenar y sustituir determinados elementos (mercancía, maquinaria deteriorada, etc.), porque en otro caso no podría administrarlo. El nudo propietario ha de facilitar esta labor mediante el deber de abstención de hacer competencia al usufructuario ${ }^{95}$.

En cuanto a la transmisión de los contratos, créditos y deudas al usufructuario, serán de aplicación los criterios mantenidos en el supuesto de la venta. Sin embargo, debe tenerse en cuenta que si se ha pactado que el usufructuario pague las deudas del nudo propietario, ha de entenderse que está obligado a pagar únicamente las anteriores a la constitución del usufructo, y que si no se ha pactado nada sobre la transmisión de las deudas, ésta se producirá si el nudo propietario no se ha reservado bienes suficientes para su pago. En cuanto a los créditos vencidos, podrá reclamarlos el usufructuario si tuviere dada o diese fianza ${ }^{96}$.

\subsubsection{Hipoteca de la empresa}

Respecto a la empresa como garantía de obligaciones, propiamente la hipoteca de la empresa, en la legislación nicaragüense no existe un derecho real de garantía sobre la empresa como objeto unitario, siendo la hipoteca únicamente constituida sobre bienes inmuebles, en consecuencia el empresario podrá hipotecar diversos derechos reales sobre elementos simples o singulares de la empresa susceptibles de dominación y persecución jurídica.

94 BROSETA, ob. cit. Pág. 92.

95 SÁNCHEZ CALERO, ob. cit. Pág. 197.

96 Idem. Pág. 198. 


\section{Revista de ODerecho}

No siendo la empresa una cosa única susceptible de soportar derechos reales distintos de los constituibles sobre algunos de sus elementos integrantes, difícilmente podrá establecerse sobre ella en su conjunto ningún derecho real de garantía. La hipoteca recae sobre inmuebles los que constituyen sólo uno de los elementos de la empresa, pero no todos. No hay gravamen

De ello podemos obtener dos conclusiones: En primer lugar, que la hipoteca mobiliaria no se constituye sobre la empresa como si fuera esta una res o una cosa, porque alguno de sus elementos quedarían fuera de ella. En segundo lugar, que la hipoteca en cuestión tiene en la ley un contenido mínimo por ella establecido. No existe, pues, hipoteca de la empresa, sino de algunos elementos de la empresa ${ }^{97}$.

Aunque otros como Rojo consideran que en la hipoteca de la empresa la extensión natural o normal -es decir, aquellos bienes o derechos que, salvo estipulación contraria en la escritura, se consideran incluidos en la hipoteca junto con el contenido esencial o mínimo- comprende el mobiliario, la maquinaria, los utensilios y los demás instrumentos de producción y trabajo, así como los signos distintivos (marcas, nombre comercial y rótulo) y además derechos de propiedad industrial e intelectual, siempre que sean propiedad del hipotecante ${ }^{98}$.

Nuestro ordenamiento jurídico, al igual que no regula el resto de formas de transmisión o negociación de la empresa, no dice nada sobre si es posible o no hipotecar la empresa como organización unitaria de elementos. Además, en su artículo 3771 del Código Civil establece que "La hipoteca es un derecho constituido sobre los bienes inmuebles o derechos reales del deudor o de un tercero en beneficio de un acreedor, para asegurar sobre los mismos el cumplimiento de una obligación”. Continúa expresando el artículo 3774 "La hipoteca de un inmueble se extiende a todos los accesorios, mientras estén unidos al principal; a todas las mejoras supervenientes al inmueble, sean mejoras naturales, accidentales o artificiales, a las construcciones hechas sobre un terreno vacío; a las ventajas que resulten de la extinción de las cargas o servidumbres que debía el inmueble; a los alquileres o rentas debidas por los arrendatarios; y al importe de la indemnización concedida o debida por los ocupadores del inmueble. Pero las adquisiciones hechas

97 BROSETA, ob. cit. Pág. 92.

98 ROJO, ob. cit. Pág. 127. 


\section{Revista de ODerecho}

por el propietario de inmuebles contiguos para reunirlos al inmueble hipotecado, no están sujetos a la hipoteca"99. Lo que nos lleva a concluir, al igual que Broseta Pont, que la hipoteca no se constituye sobre la empresa como conjunto unitario de elementos organizados, si no sobre alguno de sus elementos, pues la ley es clara al establecer una lista numerus clausus de elementos o cosas que pueden hipotecarse.

\subsection{Transmisión por causa de muerte}

La empresa como conjunto organizado de elementos, puede ser también transmitida "mortis causa". Recuérdese, en efecto, que la herencia comprende todos los bienes, derechos y obligaciones de una persona que no se extingan por su muerte ${ }^{100}$. Es obvio, que este supuesto de transmisión únicamente se da cuando el empresario transmitente es una persona natural -empresario individual-, y se regirá lógicamente por las reglas de sucesiones de nuestro Código Civil en lo que le sea pertinente.

La transmisión por causa de muerte se rige por las reglas de la sucesión por causa de muerte, siendo suficiente que el heredero acepte la empresa, y que su voluntad se manifieste hacia el exterior mediante la efectiva, concreta y actual ejecución de actos de la organización, ya que hay casos en los que aunque el heredero acepte la herencia puede no aceptar la consecuencia de convertirse en empresario, dado que si no ejercita la actividad requerida, lo heredado se limitará a un conjunto de bienes individuales ${ }^{101}$.

99 Más claro lo expresa el artículo 3799 C. Pueden hipotecarse: $1^{\circ}$ Los bienes inmuebles; $2^{\circ}$ Los otros derechos reales enajenables sobre bienes inmuebles; $3^{\circ}$ El edificio construido en suelo ajeno, el cual si se hipoteca por el que lo construyó, será sin perjuicio del derecho del propietario del terreno y entendiéndose sujeto a tal gravamen solamente el derecho que el mismo que edificó tuviere sobre lo edificado; $4^{\circ}$ Los frutos de los bienes inmuebles; $5^{\circ}$ La mera propiedad en cuyo caso, si el usufructo se consolidare con ella en la persona del propietario, no sólo subsistirá la hipoteca, si no que se extenderá también al mismo usufructo, como no se haya pactado lo contrario; $6^{\circ} \mathrm{El}$ derecho de usufructo, los pastos, aguas, leñas y otros semejantes de naturaleza real, siempre que quede a salvo el de los demás participes en la propiedad; $7^{\circ}$ Las naves; $8^{\circ}$ Los ferrocarriles, canales, puentes y otras obras destinadas al servicio público y los edificios y terrenos que, no estando directa y exclusivamente destinados al referido servicio, pertenezcan al dominio particular, si bien se hallen agregadas a aquellas obras; $9^{\circ}$ Los bienes litigiosos, si la demanda se ha anotado preventivamente, o si se hace constar en la inscripción que el acreedor tenía conocimiento del litigio ; pero en cualquiera de los dos casos, la hipoteca quedará pendiente de la resolución del pleito, sin que pueda perjudicar los derechos de los interesados en el mismo, fuera del hipotecante.

100 Artículo 934 in fine $\mathrm{C}$.

101 GUTIÉRREZ FALLA, ob. cit. Pág. 173.

JIMENEZ SÁNCHEZ, ob. cit. Pág. 70. 


\section{Reuista de Perecho}

Por supuesto, para que la transmisión a título hereditario se produzca es indispensable que tenga lugar la aceptación del heredero, que puede ser simple o a beneficio de inventario. Es obvio, que para que subsista la empresa heredada tendrá que continuar la explotación de la misma, haciéndose necesario la preservación de la administración y dirección de la empresa -que generalmente se asegura cuando el empresario fallecido hubiera designado un factor o gerente-; y la conservación de la unidad económica de la empresa.

El único acercamiento a este tipo de transmisión de la empresa por causa de muerte se puede percibir por lo establecido en el artículo 7 del CC que establece que los hijos de familia y menores pueden adquirir bienes, trabajo o industria y continuar con la labor de comercio, quedando obligados solamente hasta la concurrencia de aquellos bienes; dándole la oportunidad a los padres o tutores de éstos a continuar el comercio por cuenta del heredero, menor, debiendo obtener autorización del Juez.

\section{La compraventa de empresa: tipología específica de negocios sobre la empresa como objeto de desplazamiento patrimonial en bloque}

El negocio arquetípico de transmisión inter vivos de la empresa es la compraventa, como contrato oneroso por antonomasia, sirve de paradigma o molde de referencia obligacional para el estudio y solución de importantes problemas comunes a todos los actos de disposiciones inter vivos de la empresa, tales como la cesión de créditos, deudas y contratos pendientes de ejecución y la prohibición de competencia ${ }^{102}$. Doctrinalmente es considerado como un contrato especial, por la complejidad de su objeto, la empresa, de ahí deriva su atipicidad en la mayoría de las legislaciones inclusive la nicaragüense.

La empresa es frecuentemente objeto del contrato de compraventa. Su finalidad es transmitir al comprador de modo definitivo la titularidad de cada una de las relaciones jurídicas que ligan al empresario vendedor con cada uno de los elementos que integran la empresa, de forma que aquél pueda suceder a éste en su explotación. Pero la realidad del tráfico demuestra que, a veces, se denomina compraventa de empresa a supuestos en los que lo que se transmite no es una verdadera empresa.

102 BROSETA, ob. cit. Pág. 88. 
Sólo existirá aquel contrato cuando lo que se transmite y adquiere es un conjunto organizado de elementos en funcionamiento, en atención a la actividad económica con él realizada ${ }^{103}$.

Partiendo de la unidad meramente funcional de la empresa, el vendedor no tiene porque vender uno a uno los elementos de la empresa al comprador, sino que el objeto de la compraventa es la empresa en cuanto tal. Se debe partir, pues, de la unidad de título: un único contrato de compraventa, y no una pluralidad de ellos, es un contrato consensual y no es menester observar formas especiales ni requisito alguno de publicidad.

No obstante, cuando el titular del establecimiento sea una sociedad mercantil, es tema debatido el de si la transmisión exige acuerdo de la Junta General de socios o si, por el contrario, decidir la transmisión pertenece a la esfera de competencia propia de los administradores. Todo dependerá de los que se exprese en la escritura o estatutos de la sociedad, pero si existe silencio, y el establecimiento constituye una mínima parte debe reconocerse la competencia del órgano de administración. El precio puede estar determinado en el contrato o ser determinable ${ }^{104}$.

\section{Perfeccionamiento del contrato}

La naturaleza específica de este contrato -mercantil- implica que su objeto (la empresa) constituya, cabalmente entendido, el elemento interpretativo fundamental que hace afirmar mayoritariamente a la doctrina la naturaleza mercantil del contrato de compraventa de la empresa, por tal razón de derecho privado, aplicándose el principio de autonomía de la voluntad tanto para su perfeccionamiento como para su ejecución.

La compraventa es un contrato consensual, por ende se perfecciona entre comprador y vendedor, desde el momento en que hubiese consentimiento sobre el objeto y el precio, si bien esto no tiene efecto frente a terceros hasta que ocurra el cumplimiento de los requisitos y formalidades requeridas. 


\section{Reuista de Derecho}

Para la existencia de este negocio jurídico bastará la estipulación de un único contrato, cuyo objeto sea la transmisión de la empresa misma, sin que deban estipularse tantos negocios cuantos elementos individuales la compongan. Esto no obstante, para la entrega (traditio) de cada elemento será indispensable respetar su propia ley de circulación. Para la perfección del contrato es aplicable el principio de libertad de forma ${ }^{105}$. Vicisitudes propias de la compraventa de empresa

\section{- Vicios del consentimiento}

El artículo 2455 del Código Civil considera que "Es anulable el contrato en que se consiente por error, cuando éste recae: $1^{\circ}$ Sobre la especie del acto o contrato que se celebra. $2^{0}$ Sobre la identidad de la cosa especificada de que se trata, o sobre su sustancia o calidad esencial". Conociendo que por error se entiende la opinión subjetiva contraria a la realidad o la discrepancia entre la voluntad interna y la voluntad declarada. Y que existen cuatro clases de errores posibles a saber: a) el error obstáculo o error independiente, cuando recae sobre la naturaleza del contrato o sobre la identidad de la cosa [el error in negotio y el error in corpore que hacen inexistente el consentimiento; b) el error-nulidad o error-vicio, que hacen anulable el contrato; c) el error indiferente, que afecta la validez del contrato y que ordinariamente se reduce a contratar en condiciones más onerosas o desfavorables de las que se pensó, y d) los errores de cálculo, que no vician el consentimiento ${ }^{106}$.

Por regla general se aplican a los vicios, en esta clase de contratación sobre la empresa las mismas reglas establecidas en la legislación civil, aunque la empresa es un bien complejo compuesto de diferentes elementos entrelazados entre sí. El error in corpore será vicio del consentimiento únicamente en aquellos casos en que afecte la organización misma o una de sus características esenciales. El vendedor no garantiza la rentabilidad de la misma, ya que ésta va a depender de las habilidades del comprador, si bien podría tipificar como caso de dolo si el vendedor hizo creer injustificadamente al comprador de la empresa que había estado percibiendo ingresos de consideración, cuando lo cierto es que eran perdidas, u oculte pasivos directos o contingenciales, por lo que se recomienda que en el contrato se transcriba un balance general de la

105 BENDAÑA GUERRERO, Estudio de los contratos, 2001, 57.

106 GUTIÉRREZ FALLA, ob. cit. Pág. 181. 


\section{Revista de ODerecho}

empresa cedida garantizando que el mismo refleja la verdadera situación financiera del negocio ${ }^{107}$.

- Delimitación del objeto del contrato

En el plano doctrinal este contrato es considerado como compraventa especial por razón de su objeto, que es la empresa.

Del propio negocio tal como se haya redactado debe aparecer con la mayor claridad posible si el objeto del mismo es la transmisión integral del conjunto de la empresa o la de una parte de la misma o la de determinados elementos integrados en ella. Delimitado el objeto, deberá completarse con la relación o inventario pormenorizado de los elementos que se integran en el objeto del negocio.

La configuración del tipo negocial está determinado básica y preponderantemente por la especificidad propia del objeto transmitido: la empresa. Sólo cuando lo que se transmite definitivamente es un conjunto organizado de elementos en funcionamiento, esto es, una unidad de explotación comercial o industrial, formado por capital y trabajo, y dirigida y organizada por su titular, el empresario transmitente, podrá existir compraventa de empresa ${ }^{108}$.

\section{- Aspectos relevantes en la negociación del contrato}

En la negociación de la transmisión de una empresa habitualmente suelen tenerse en cuenta determinados aspectos. En primer lugar, el transmitente debe asegurarse de que la información que sobre la misma se ofrezca al adquirente potencial tendrá carácter confidencial, por lo que a veces es necesaria la firma de un pacto de confidencialidad. Esa información proporcionada por el transmitente, deberá comprender toda la documentación de la empresa: documentación contable y fiscal, títulos de propiedad, contratos laborales, contratos con suministradores y clientes, contratos con terceros, inventarios, documentación tecnológica; dicha actividad de comprobación es lo que se conoce en lenguaje anglosajón como "due diligense".

Y en segundo lugar habrá que tomarse en cuenta el cálculo de las posibles contingencias, deudas desconocidas en el momento de la transmisión a 
las que el adquirente puede verse obligado a hacer frente: un ejemplo las deudas fiscales; ante estas posibles dificultades suele pactarse el depósito de garantía de una parte del precio en una entidad financiera ${ }^{109}$.

- Obligaciones derivadas de este contrato

Del contrato de compraventa de la empresa nacen las clásicas obligaciones de entregar la cosa y de pagar el precio. Su especial naturaleza hace surgir obligaciones sui generis tales como:

Para el vendedor:

a) Obligación de entregar la empresa vendida, que según se haya confeccionado el inventario se entregarán todos los elementos comprendidos en éste. En ausencia de inventario, el vendedor debe entregar todos los elementos esenciales de la empresa, de forma que el adquirente pueda continuar su explotación por haber recibido no sólo los elementos aislados que la componen sino la "organización" productiva que es la empresa. La clásica obligación, a cargo del vendedor (o cedente), de entrega de la cosa o bien objeto de transmisión está sujeta a las siguientes reglas:

i) La determinación de los elementos patrimoniales que deben ser entregados al comprador (o adquirente), aun siendo una cuestión de hecho que ha de dilucidarse en cada caso, tiene que resolverse con criterios de naturaleza técnica y jurídica. En todo caso, el vendedor (transmitente) a de entregar todos los elementos esenciales, materiales e inmateriales, de la empresa necesarios para que el adquirente pueda continuar con normalidad la actividad empresarial en las mismas condiciones jurídicas y niveles de productividad o rentabilidad.

ii) Tratándose de una empresa, la entrega efectiva se descompone y pluraliza patrimonialmente en este "trance traditoro", de modo que su entrega requerirá una pluralidad de transmisiones particulares de sus distintos elementos simples, sujetas cada una de ellas a la ley de circulación propia del bien o elemento que deba transmitirse ${ }^{110}$.

109 No obstante, la variedad de transmisiones particulares que deban darse, según nuestra legislación, la compraventa produce la transmisión del dominio de la cosa vendida junto con los riesgos, $2530 \mathrm{C}$. en adelante.

$110 \mathrm{Al}$ respecto el Código de Comercio nicaragüense expresa en el artículo 46. "Los comerciantes conservarán los libros, telegramas y correspondencia de sus giros en general, por todo el tiempo que éste dure y hasta diez años después de la liquidación de todos sus negocios y dependencias mercantiles. 


\section{Revista de Derecho}

Véase: los bienes inmuebles se transmiten mediante otorgamiento de escritura pública e inscripción en el Registro de la Propiedad, los bienes muebles sólo requieren su entrega material o puesta a disposición, o incluso la mera entrega simbólica. Los llamados bienes inmateriales de propiedad industrial (marcas, patentes, modelos de utilidad, nombres comerciales) deben transmitirse mediante documento fehaciente e inscribir su transmisión. La cesión de créditos incorporados a títulos valores se ha de ajustar a las normas de circulación propias de cada clase de título (la mera entrega, para los títulos al portador; el endoso para los títulos a la orden; y para los títulos nominativos directos, su entrega y la notificación de la cesión al deudor). Para la cesión de créditos no incorporados a títulos valores basta, además del pacto transmisivo, la mera notificación al deudor de dicha cesión.

Los contratos en curso estipulados entre el empresario o cedente y los terceros (contratos de suministro, de arrendamiento distinto del local de negocio, de licencia de explotación de patentes, de seguro, de banca, de trabajo, etc.) imprescindibles para la actividad de la empresa o coadyuvantes de ésta, se transmiten bien de modo convencional, con el doble acuerdo, uno entre el cedente y adquirente y otro (fundamental) entre éste y el tercero al tratarse de una subrogación contractual.

Las relaciones de hecho, ya sea con personas (clientes proveedores, agentes intermediarios, etc.) o con el conocimiento y funcionamiento de los procedimientos técnicos (patentes, licencias de patentes, secretos industriales -el llamado know how-) o los sistemas o estructuras de la organización comercial de la empresa requieren para su transmisión la imposición al vendedor o cedente de una serie de obligaciones de hacer y no hacer.

Respecto a los libros de contabilidad se entiende que el transmitente, si bien los ha de conservar debe ponerlos a disposición del adquirente ${ }^{111}$.

Se presume que los herederos del comerciante tienen los libros de éste, y están sujetos a exhibirlos en la misma forma y los términos que estaría la persona a quien heredaran.

Los documentos que conciernan especialmente a actos o negociaciones determinadas, podrán ser inutilizados o destruidos, pasado el tiempo de prescripción de las acciones que de ellos se derivan, a menos que haya pendiente alguna cuestión que se refiera a ellos directa o indirectamente, pues en tal caso, deberán conservarse hasta la terminación de la misma".

111 BERCOVITZ, ob. cit. Pág. 72. 


\section{Revista de Derecho}

Respecto a las reglas referidas a la transmisión de las deudas de la empresa contraídas por el empresario cedente, las partes deben pactar la cesión de éstas, aunque en principio, sólo las de naturaleza contractual y no las extracontractuales se transmiten; ese pacto ha de ser expreso, o de lo contrario se entenderá que dichas deudas no se transmiten con la empresa ${ }^{112}$.

b) Obligaciones accesorias: la especial naturaleza de la empresa como organización impone ciertas obligaciones accesorias: entregar listas de clientes, comunicar a éstos por circulares la enajenación realizada, asesoramiento en la producción (know how), comunicación de secretos de fabricación, etc. y, especialmente prohibición de competencia ${ }^{113}$.

c) Finalmente el vendedor de la empresa está obligado al saneamiento ${ }^{114}$. Debe tenerse en cuenta que el objeto de la compraventa es un bien económicamente complejo, por ende los vicios que pudieran afectar alguno de los elementos individuales o la no entrega de alguno de éstos, salvo que fuesen esenciales para el ejercicio de la actividad empresarial, no serían motivo para resolver el contrato, sino, en todo caso, para exigir una rebaja proporcional del precio ${ }^{115}$.

Si bien ha de aplicarse a la compraventa de la empresa las reglas sobre el saneamiento para el caso de evicción, vicios ocultos, etc., el vicio debe afectar la organización en sí de forma que la empresa vendida no sirva para el fin para el cual fue adquirida.

En cuanto a las obligaciones para el comprador, la obligación esencial es la de pagar el precio. En la práctica es frecuente que el comprador retenga parte del precio hasta que se realice el inventario o se practique una auditoría o hasta que desaparezca el riesgo de determinadas contingencias (fiscales, laborales). ${ }^{116}$

- Ejecución de la transmisión

Comoya se ha expuesto reiteradamente, una vez pactada la transmisión de la empresa, habrá que cumplir lo acordado, transmitiendo la titularidad

112 BROSETA, ob. cit. Pág. 88-89.

113 A falta de regulación especial tomar en cuenta lo que sobre evicción establece el Código Civil nicaragüense en su artículo 2600 en adelante.

114 GUTIÉRREZ FALLA, ob. cit. Pág. 180.

115 ROJO, ob. cit. Pág. 125.

116 JIMENEZ SÁNCHEZ, ob. cit. Pág. 70. 


\section{Revista de ODerecho}

de cada elemento integrante de aquella según las normas legales que rigen para la transmisión de cada elemento según su naturaleza jurídica.

El título jurídico que liga al empresario con su empresa no se puede reducir de un modo absoluto y simplista al que proviene de un derecho real de propiedad sobre la empresa. La naturaleza especialmente compleja de este objeto jurídico empresarial, obliga a hablar de "titularidad de la empresa" más que de "propiedad de la empresa" para explicar la naturaleza o título de relación del empresario con su empresa. De aquí que por la compraventa de empresa se transmite al adquirente la "titularidad" de cada uno de los elementos y relaciones fácticas y jurídicas que ligan al empresario transmitente con cada uno de los elementos que conforman el complejo objeto jurídico empresarial ${ }^{117}$. Como se explicó se parte de la unidad de título. Pero, si el título es único, el modo o tradición es plural, es decir, que está en función de la naturaleza de cada uno de los elementos que componen el establecimiento. En efecto para la transmisión de los singulares bienes es preciso respetar las exigencias y las formas que la ley establece respecto de cada uno de ellos. Si la compraventa se hace en escritura pública, el otorgamiento de ésta equivale a la entrega de todos y cada uno de los elementos del establecimiento. La necesidad de cumplir estos requisitos, sin embargo, no empaña la validez del contrato consensual en que se enajene el establecimiento como un todo único, y, una vez prestado el consentimiento, las partes podrán compelerse recíprocamente a cumplir con aquellos requisitos exigidos por la ley para la transmisión de los distintos bienes que lo integran ${ }^{118}$.

Si la transmisión se formaliza en escritura pública producirá la transmisión con los efectos reales en general de todos los bienes muebles e inmuebles y restantes derechos integrantes de la empresa que se transmite.

Para la transmisión de los créditos será necesaria la notificación al deudor ${ }^{119}$ y para la transmisión de las deudas será preciso el consentimiento del acreedor ${ }^{120}$.

117 ROJO, ob. cit. Pág. 124.

118 Art. 2720 C.

119 Nuestro Código Civil acepta la cesión de créditos, pero con relación a la cesión de deudas guarda silencio, no la contempla pero tampoco la prohíbe. Parece necesario por tanto, para garantía de la eficacia de este contrato que el acreedor preste su consentimiento a esta transmisión.

120 BERCOVITZ, Ob. cit. Pág. 270-271. 


\section{Revista de ODerecho}

Especial problema plantea la transmisión de los clientes. Hay que señalar que no siempre que hay una transmisión de una empresa se pretende que con ella de transmita también la clientela, pero lo normal es que si. Sólo se puede transmitir jurídicamente la clientela transmitiendo los contratos de duración que liguen al empresario transmitente con sus clientes. Pero en general la clientela ha de transmitirse por medios indirectos, esto es, mediante la transmisión de los signos distintivos de la empresa, la entrega de las listas de clientes, la colaboración positiva consistente en presentar al nuevo empresario y recomendar la continuación de los negocios con él, y sobre todo asumiendo el transmitente la obligación negativa de abstenerse de competir durante el tiempo que ha de ser razonable y en el ámbito geográfico en el que se desarrolle la participación en el mercado de la empresa transmitente, dicha obligación conviene estipularla por escrito $^{121}$.

\section{Conclusiones}

1. En la actualidad el Derecho Mercantil se configura como un ordenamiento profesional de empresa, lo que no nos debe llevar a identificar al Derecho Mercantil con el derecho de la empresa.

2. El término comerciante empleado por nuestro arcaico Código de Comercio en la actualidad jurídica, económica y social fue sustituido por el de empresario, noción mucho más amplia que comprende un sinnúmero de actividades. Empero, aun nuestro Código de Comercio nicaragüense, denomina a este sujeto jurídico "comerciante" y no "empresario", lo cual es una denominación inexacta.

3. En nuestra realidad jurídica, y en la de la mayoría de legislaciones, no existe un concepto jurídico de empresa univoco, que permita sin equivocaciones aplicar un régimen jurídico exacto a los problemas generados por su transmisión.

4. Al ser considerada la empresa como un conjunto organizado de elementos de variada condición y naturaleza, cada uno de los cuales se ve sometido al régimen jurídico propio de esa naturaleza, no significa que no puede transmitirse de manera unitaria ésta.

5. Se diferencian en dos los tipos de transmisión de la empresa la que se puede dar en forma directa o en indirecta, lo que nos lleva a concluir que no deberá confundirse la venta de acciones de una sociedad como forma de transmisión de la empresa como objeto del negocio.

121 GÓMEZ PORRÚA Juan Manuel, "La Tarjeta de Crédito" en Derecho Mercantil, Vol. II, 4a edición, dirigido por Jiménez Sánchez, Guillermo, Editorial Ariel S.A., Barcelona 1990 y 1997, página 189. 


\section{Revista de ODerecho}

6. En el ordenamiento jurídico nicaragüense participan una serie de normas legales tales como la Ley de Marcas y la Ley de Equidad Fiscal que, sin llegar a desarrollar las transferencias de empresas, se refieren a éstas, lo que viene a significar que la misma no es totalmente atípica en el Derecho positivo nicaragüense.

7. Por antonomasia, el negocio arquetípico de transmisión inter vivos de la empresa es la compraventa de empresas, el cual no está desarrollado por nuestro ordenamiento jurídico, pero en virtud del principio de "la autonomía de la voluntad" y "libertad de contratación" puede realizarse en nuestra realidad jurídica, claro ésta, apoyándose por analogía en las distintas normas que deban ser aplicadas.

\section{Recomendaciones}

1. Es conveniente trabajar en el Derecho positivo nicaragüense en la elaboración de un concepto jurídico de empresa aplicable a todas las normas jurídicas que regulen ésta, dicho impulso debe comenzar desde las universidades.

2. De la misma manera, se debe trabajar legislativamente en la configuración y desarrollo de instrumentos jurídicos que tipifiquen las distintas maneras de transmisión de la empresa.

3. Cada casa de estudio universitaria debe cultivar constantemente en los alumnos conocimientos precisos para diferenciar que la empresa no es equivalente a sociedad o empresario, el cual es titular de la misma; e incluir en los programas de estudios el impacto de los diferentes negocios jurídicos que se pueden hacer con la empresa cuando ésta es el objeto de transmisión.

\section{Bibliografía}

\section{Textos}

BENDAÑA GUERRERO, Guy, Estudio de los contratos, PAVSA, Nicaragua, 2001.

BERCOVITZ RODRÍGUEZ- Cano, A., Apuntes de Derecho Mercantil, Derecho de la Competencia y Propiedad Industrial, $3^{\mathrm{a}}$ ed., Ed. Arazandi, España,2002. 
BROSETA PONT, M., Manual de Derecho Mercantil, T.I, $11^{\mathrm{a}}$ ed., Ed. Tecnos, S.A., España,2003.

BAUCHE GARCIADIEGO, Maurio, La Empresa, Porrua, México, 1977.

CABANELLAS DE TORRES, Guillermo, Diccionario jurídico elemental, 15 ${ }^{\mathrm{a}}$. Ed., Argentina, Editorial Heliasta S.R.L., 2001.

DÍEZ PICAZO, Luis, Sistema de Derecho Civil, TECNOS, Madrid, 1978.

DÍEZ PICAZO, Luis, Fundamentos del Derecho Civil patrimonial, T.I, Civitas, Madrid, 1996.

DÍEZ PICAZO, Luis, Sistema de Derecho Civil, Vol. III, TECNOS, Madrid, 2002.

ESCOBAR FORNOS, Iván, Derecho de Obligaciones, $2^{\mathrm{a}}$ ed., Hispamer, Nicaragua, 2000.

FERNÁNDEZ FERNÁNDEZ, Diccionario de Derecho Empresarial, 1998,

FONT GALÁN, Juan I. "La empresa como objeto de negocios jurídicos”, en Derecho Mercantil, V I, Coordinador: Guillermo Jiménez Sánchez, Ed. ARIEL, España, 2000, Pág. 75 a 107.

GIRÓN TENA, José., Apuntes de Derecho Mercantil, La Empresa, Tecnos, 1977- Madrid,1978.

GUZMÁN GARCÍA, Jairo José, Apuntes de derecho de cosas, Material para el curso de la Licenciatura. 2007.

HERRERA ESPÍNOZA, Jesús Jusseth, Derecho Mercantil I, Educación a Distancia, Nicaragua, 2008.

JIMENEZ SÁNCHEZ, Guillermo, Lecciones de Derecho Mercantil, MCGRAW-HILL, España, 2004.

LACRUZ BERDEJO, Nociones de Derecho civil patrimonial $e$ introducción al Derecho, $6^{\text {a }}$ ed., José Ma. Bosch, Barcelona, 1992. 
PÉREZ DE LA CRUZ, Antonio, La propiedad industrial e intelectual (I) teoría general, en Curso de Derecho Mercantil I, Coordinador: R. Uría, Ed. Civitas Ediciones S.A., España, 1999.

RIBÓ DURÁN, Diccionario de Derecho Empresarial, 1998.

ROJO,Ángel, «Elempresario(I).Concepto,ClasesyResponsabilidades», «El Establecimiento mercantil», en Curso de Derecho Mercantil, I, Coordinador: R. Uría, Ed. Civitas Ediciones S.A., España, 1999.

SÁNCHEZ CALERO, Fernando, Instituciones de Derecho Mercantil, v.1, $24^{\text {a }}$ ed., España, Ed. McGraw-Hill, 2002.

\section{Módulos Autoformativos}

GONZÁLEZ RIEGA, Gerardo, Ponencia sobre Derecho Patrimonial Civil, UCA, abril 2008.

\section{Legislación}

Constitución Política de la República de Nicaragua.

Código Civil de la República de Nicaragua.

Código de Comercio de la República de Nicaragua y sus reformas.

Código del Trabajo de la República de Nicaragua.

Ley No. 499, Ley General de Cooperativas, Publicada en La Gaceta, Diario Oficial No. 17 del 25 del enero del 2005.

Ley No. 453, Ley de Equidad Fiscal, Publicada en La Gaceta, Diario Oficial No. 82 del 6 de mayo del 2003.

Ley No. 147, Ley General sobre Personas Jurídicas sin Fines de Lucro, Publicada en La Gaceta, Diario Oficial No.102 del 29 de mayo de 1992. 
Ley No. 380, Ley de Marcas y Otros Signos Distintivos, Publicada en La Gaceta, Diario Oficial No. 70 del 16 de abril del 2001.

Ley No. 354, Ley de Patentes de Invención, Modelos de Utilidad y Diseños Industriales, Publicada en La Gaceta, Diario Oficial de fechas 22 y 25 de septiembre del 2000.

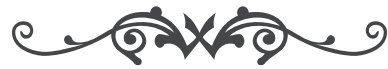

